Article

\title{
Is Cr-Spinel Geochemistry Enough for Solving the Provenance Dilemma? Case Study from the Palaeogene Sandstones of the Western Carpathians (Eastern Slovakia)
}

\author{
Katarína Bónová $^{1, *}$, Tomáš Mikuš ${ }^{2}$ and Ján Bóna ${ }^{1}$ \\ 1 Institute of Geography, Faculty of Science, Pavol Jozef Šafárik University in Košice, Jesenná 5, 04001 Košice, \\ Slovakia; jan.bona@upjs.sk \\ 2 Earth Science Institute, Slovak Academy of Sciences, Geological Division, Dumbierska 1, \\ 97401 Banská Bystrica, Slovakia; mikus@savbb.sk \\ * Correspondence: katarina.bonova@upjs.sk; Tel.: +421-55-234-2587
}

Received: 18 October 2018; Accepted: 20 November 2018; Published: 23 November 2018

\begin{abstract}
The provenance of the Proč and Strihovce sandstones is crucial for understanding the relationship between the Pieniny Klippen (PKB) and Flysch (FB) belts in the easternmost part of the Western Carpathian realm. Detrital Cr-spinels in these tectonic units were assertively interpreted as sourced from the southern sources representing the Meliata mélange. In this study, we use the geochemistry of detrital chromian spinels to identify the mafic and ultramafic source of the sediments and to compare them each other. Simultaneously, we compare their chemical compositions with those from the different Western Carpathian geological units, which could feed the Proč and Krynica basins during the Paleogene, where the Proč and Strihovce formations (fms), respectively, were deposited. Chromian spinels from the Proč and Strihovce fms exhibit similar geochemical characteristics $\left(\mathrm{Cr} \#=0.44-0.88\right.$ and $0.29-0.89, \mathrm{Mg} \#=0.17-0.68$ and $0.2-0.72, \mathrm{TiO}_{2}=0.0-3.67$ and 0.01-2.08 wt.\%, respectively). The spinels show both supra-subduction zone (SSZ) peridotite signatures and volcanic origin. Whereas volcanic spinels from the Proč Formation (Fm.) were formed under an ocean island basalt (OIB) and back-arc basin basalt (BABB) geodynamic setting, those from the Strihovce Fm. suggest a predominantly mid-ocean ridge basalt (MORB) origin. To avoid mistakes in the provenance interpretations, the data from garnet geochemistry of both formations is supplied. The analysed Cr-spinels do not absolutely overlap with spinels reported from the Meliata Unit, and their composition indicates at least two independent sources.
\end{abstract}

Keywords: Cr-spinel; garnet; geochemistry; provenance; Pieniny Klippen Belt; Magura Unit; Western Carpathians

\section{Introduction}

Heavy mineral (HM) analysis has remained a useful method in the study of sediments. Knowledge of the behaviour of heavy minerals in a wide range of sedimentary environments has increased in parallel with the growing understanding of sedimentary processes and factors operating in depositional environments [1-4]. Weathering, transport and diagenetic conditions at the depositional site significantly influence the composition of heavy mineral suites. These processes may modify the original sediment composition and complicate the provenance interpretations [5,6]. Suitable solutions seem to focus on the chemical composition of mineral species, such as garnet [7-10], tourmaline [11], rutile [12] or Cr-spinel [13-15], etc. In this study, we focused predominantly on Cr-spinel geochemistry and garnet composition. These detrital minerals seem to be appropriate for specifying the potential 
lithologies exposed in the source area(s) with regard to the ophiolite provenance. In addition, pyrope-rich garnets were searched during this research. These likely originated from mantle-derived rocks and/or high-grade metamorphic rocks $[10,16]$. Detrital chromian spinels in sedimentary rocks are useful for discriminating among potential mafic and ultramafic sources $[15,17,18]$. Cr-spinels often represent exclusive heavy minerals derived from parent ultramafic rocks, whereas the minerals typical of these rocks, such as olivine, pyroxene or amphibole, are preserved in sedimentary deposits more sporadically [5-7]. Consequently, detrital Cr-spinels are usually used in provenance considerations and palaeogeographic reconstructions of ophiolite sources [13,19-25]. The geochemistry of the detrital Cr-spinels can profitably be used to trace specific mafic and ultramafic sources of clastic wedges derived from collisional orogens [26].

In the Western Carpathian realm, chromian spinels have been geochemically studied in different spinel-bearing geological units, such as the meta-ultramafic rocks of the Tatric Unit $[27,28]$ and the ultramafic bodies of the Meliata Unit [29,30]. Detrital Cr-spinels have been recognised in the Triassic Lunz Formation [31], in the Mesozoic Pieniny Klippen Belt (PKB) deposits [21,32-36], in the Cretaceous Poruba Formation cropping out in the Tatric and Fatric units [33,37,38], and, moreover, in sediments from the Šambron-Kamenica zone in the Central-Carpathian Palaeogene basin (CCPB) outcropping in the south margin of the PKB in the Eastern Slovakia [24,39], in the Gosau Group deposits [37,40], and also in the siliciclastic rocks from the Magura Nappe [32,41-43]. Detrital Cr-spinels in Triassic sedimentary rocks were interpreted as being of extra-Carpathian origin [31], while Albian sediments cropping out in the Czorsztyn Unit (PKB) and Cretaceous Poruba flysch sediments could be derived from the Meliata mélange [36,37]. The preliminary spinel geochemical data from the Eocene Magura Fm. sandstones of the Magura Nappe suggest that Cr-spinels were supplied only from harzburgitic ophiolites of the Vardar zone sub-province [41]. An ophiolite source consisting of the harzburgitic mantle peridotites developed mainly in a supra-subduction zone setting was proposed for the Eocene to Oligocene Magura flysch formations [43]. Extensive detrital Cr-spinels of these formations originated in volcanic source rocks, and they could be derived from the Fore-Marmarosh suture zone in the Eastern Carpathians [43]. Cr-spinels were also found within pebbles of Cretaceous Orbitolinae limestones, which are the constituents of turbidite sandstones of the Strihovce Fm., as well as the Proč Fm. [35,44].

Ophiolitic detritus, such as serpentine or Cr-spinels found in the flysch deposits of the CCPB, indicate existence of the suture located at the transition between the Inner and Outer Western Carpathians [45]. Ophiolitic rocks have also been found as blocks of ophicalcites penetrated by limestone dykes in the western segment of the Magura Unit [46]. These rocks were inferred to be the Alpine-type ophiolites, related to the Magura basement [46].

There have been several provenance studies based on exotic pebble occurrences, sandstone petrography and heavy mineral assemblages, combined with palaeocurrent data, regarding the Strihovce Fm. [35,43,47,48], while the information on the Proč Fm. provenance is poor [44]. Detrital Cr-spinels are widely found in the Strihovce sandstones [32,43,48-50], whereas their accurate content in the Proč sandstones is largely enigmatic. Cr-spinels have been identified as a component of Cretaceous limestone pebbles in the Proč conglomerate [44,51]. These authors associated their occurrence to Jurassic-Cretaceous basic volcanism in the Eastern Carpathians.

This study reports detailed Cr-spinel microprobe data from both of the mentioned formations (1) to recognise the possible compositional variations between them; (2) to determine whether the Proč and Krynica basins (where the Proč and Strihovce fms were deposited, respectively) could have separate source areas or not in order to better characterise the relationship between them and between the Pieniny Klippen and Flysch belts in the easternmost segment of the Western Carpathians; and (3) to point out that detrital spinel geochemistry is sufficient for solve of this dilemma. The geochemical data for an abundant, relatively stable garnet is supplemented. Therefore, this study offers the first information on the geochemistry of detrital spinel and garnet from the Proč Fm. 


\section{Geological Background}

The Western Carpathians-a component of the Alpine-Carpathian mountain chain-consist of the Outer Western Carpathians (Flysch Belt) and the Inner Western Carpathians, separated by the narrow zone named the Pieniny Klippen Belt [52].

The Magura Nappe is the largest tectonic unit in the Outer Western Carpathians. The thick flysch complexes outcropping north of the Pieniny Klippen Belt are a result of deep-sea turbiditic Cretaceous to Late Oligocene (eventually Early Miocene) sedimentation in the Magura Basin [53-55], Paleogene-Miocene deformation caused by gradual subduction of the oceanic realms (the Valais-Rhenodanubian-Magura and the Piemont-Liguria-Vahic domains) [56,57] and growth of the orogenic accretionary wedge (e.g., [58,59]).

The innermost part of the Magura Nappe is formed by the Krynica tectono-lithofacies unit, which outcrops along the northern margin of the Pieniny Klippen Belt (PKB, Figure 1a,b). In general, the Krynica Unit consists of the Proč, Strihovce and Malcov formations in the studied area [60,61].

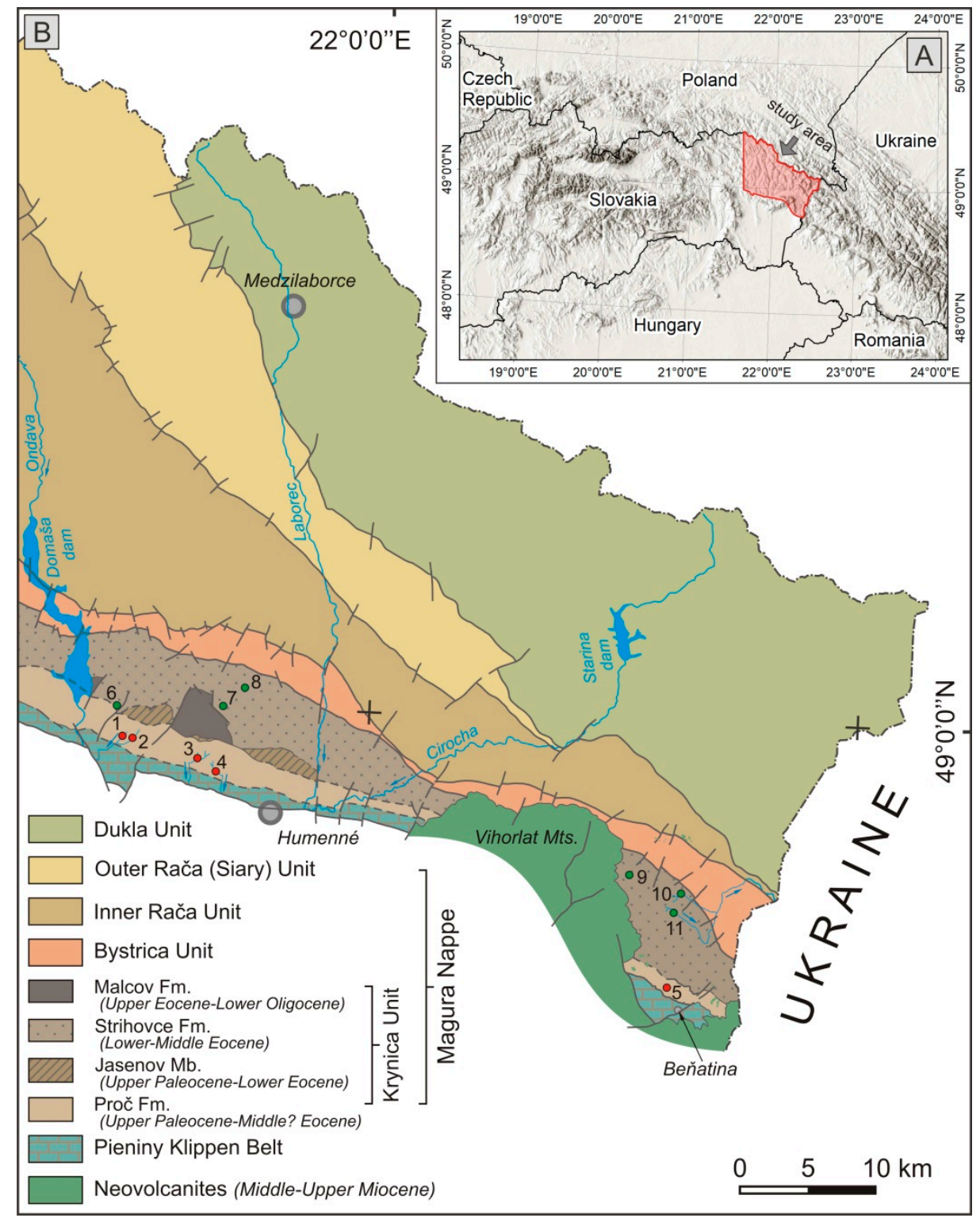

Figure 1. (a) Position of the studied area in Central Europe; (b) Simplified structural sketch map of the NE part of the Western Carpathians according to Žec et al. [60,62] and Geological map [63] with sampling locations: red circles (samples 1-5)—Proč Fm.; green circles (samples 6-11)—Strihovce Fm. 
The Upper Palaeocene-Middle? Eocene Proč Fm. is formed by quartz-calcareous sandstone and grey-greenish claystone with intercalations of conglomerate $[60,62,64]$. The sandstone is classified as calclithic arenite [54]. It consists of carbonate clasts (30-59\%), quartz (monocrystalline 9-11\%, polycrystalline $4-7 \%$ ), cherty clasts (up to $3 \%$ ), plagioclase $(3-7 \%$ ) and K-feldspar (up to $4 \%$ ). Clastogenic micas and glauconite are scarce. The pore-filling material has up to $26 \%$ calcite cement [54]. The Jasenov Beds (Upper Palaeocene-Lower Eocene) represent the recurrent facial transition between the Proč and Strihovce formations. This member is distinguished by the discontinuous outcropping of both lithofacies; the Proč lithofacies (quartz-calcareous well sorted sandstone) and the Strihovce lithofacies (quartz-greywacke sandstone) alternate in short segments. The Strihovce Fm. (Lower-Middle Eocene) forms the most extended part of the Krynica Unit. It consists of quartz-greywacke sandstone with intercalations of claystone, polymict and monomict conglomerates, and rarely of submarine slump bodies [54,62]. The sandstone is classified as subarkose, sublitharenite and calclithic arenite [54]. Most of the grains are quartz (monocrystalline 13-49\%, polycrystalline up to $21.2 \%$ ), cherty clasts (up to $12 \%$ ), plagioclase (up to $10 \%$ ) and K-feldspar (up to $8.5 \%$ ). Micas and glauconite are also present (up to $6 \%$ and $4 \%$, respectively). Calcite cement is predominant (up to $34.5 \%$ ) over clay matrix (up to $10.7 \%$ ). Lithic fragments cover a wide range of rocks from the sedimentary and metasedimentary to igneous origin (granites, lesser felsic volcanites) [54]. The Upper Eocene-Lower Oligocene Malcov Fm. is locally developed in the studied area. It consists predominantly of calcareous dark-grey claystone beds with sporadic sandstone intercalations and Menilite Beds. In the eastern part of this area, there is a complex formed by variegated calcareous claystones known as the Inovce Fm. (Middle-Upper Eocene) [62].

Leško [65] defined the Proč Fm. as a structurally independent Palaeogene cover of the PKB, known as the "Beňatina flysch" [64,66]. Nemčok et al. [67] proposed the Proč-Jarmuta Fm. as the dominant complex of the "klippen mantle"; thus, the complex was developed in the overlier of the older klippen successions. Nowadays, two different opinions related to the tectonic adherence of the Proč Fm. exist:

Potfaj and Rakús, in Žec et al. [62], suggest that the sedimentary sequences deposited before the Maastrichtian, including the Jarmuta Fm., belong to the PKB; whereas the Palaeogene Proč Fm. was relegated to the Magura Unit, also known as the "Magura Palaeogene s. 1". It is important to note that there is a facial interconnection between the Proč and Strihovce fms, referred as the Jasenov Mb., defined by Potfaj in Žec et al. [60] in the studied area. This indicates that the Proč Fm. (eastwards of Domaša dam, Figure 1b) is a component of the Krynica Unit $[54,60,61,68]$ with the Magura provenance.

Plašienka and Mikuš [69] consider the Jarmuta and Proč fms to be constituents of the Šariš Unit (Oravic superunit), which is in the lowermost structural position of the PKB in eastern Slovakia. According to these authors, it is not possible to distinguish the Jarmuta and Proč fms in the north-western part of the PKB in eastern Slovakia (between Litmanová and Drienica villages) from each other, and therefore to define them cartographically.

Following the references mentioned above [69,70], the Jarmuta and Proč fms are mutually linked in the eastern Slovakian region. Nemčok et al. [67] also noticed their mutual lithological conjunction and intensive tectonic reworking.

Interestingly, the Palaeocene-Lower Eocene quartz-calcareous sandstone and calcareous claystone of the Proč Fm. (Brvnište slice) outcropping in the western segment of the Flysch Belt was matched to the Biele Karpaty group of nappes, not to the PKB [71].

\section{Analytical Methods}

Five fine- to coarse-grained sandstone samples weighing around 15-20 kg were collected from the Proč Fm., and six fine- to coarse-grained samples with the same weight were collected from the Strihovce Fm. deposits. The sampling sites are depicted in Figure $1 \mathrm{~b}$ and in Table 1. Spinels and garnets were separated from sandstone by the standard methods. Heavy mineral concentrates obtained from compact sedimentary rocks and panned concentrates acquired from the recent alluvium network were 
prepared. The sampling sites for the panned concentrates were located in perennial streams, which contain only the studied lithologies to avoid contamination (Figure 1b). HM concentrates (fractions under $0.5 \mathrm{~mm}$ ) were qualitatively and quantitatively evaluated. Totals of 300-350 translucent grains were optically evaluated (Table 2). Cr-spinels and garnets were selected by hand-picking, before being mounted in epoxy and polished for analysis. Composition of Cr-spinels was determined using a JEOL JXA 8530FE (Earth Science Institute in Banská Bystrica, Slovak Republic) under the following conditions: accelerating voltage $15 \mathrm{kV}$, probe current $20 \mathrm{nA}$, beam diameter 2-3 $\mu \mathrm{m}$, ZAF correction, counting time $10 \mathrm{~s}$ on peak, $5 \mathrm{~s}$ on background. Used standards, X-ray lines and D.L. (in ppm) are: $\mathrm{Ca}(\mathrm{K} \alpha, 25)$-diopside, $\mathrm{K}(\mathrm{K} \alpha, 44)$-orthoclase, $\mathrm{Na}(\mathrm{K} \alpha, 43)$-albite, $\mathrm{Mg}(\mathrm{K} \alpha, 41)$-olivine, $\mathrm{Al}(\mathrm{K} \alpha$, 42)—albite, $\mathrm{Si}(\mathrm{K} \alpha, 63)$ - quartz, $\mathrm{Fe}(\mathrm{K} \alpha, 52)$ - hematite, $\mathrm{Cr}(\mathrm{K} \alpha, 113)-\mathrm{Cr}_{2} \mathrm{O}_{3}, \mathrm{Mn}(\mathrm{K} \alpha, 59)$-rhodonite, $\mathrm{V}(\mathrm{K} \alpha, 117)-\mathrm{ScVO}_{4}, \mathrm{Ti}(\mathrm{K} \alpha, 130)$-rutile. To avoid inaccurate results, analyses close to grain cores and rims, and away from micro-veins or altered zones, were selected. Representative geochemical data are listed in Table 3. Back-scattered electron (BSE) images were performed to provide a textural framework for the studied minerals. The chemical analyses of detrital garnets were obtained using the same instrument under identical conditions, and these are listed in Table 4. SEM-EDX (TESCAN VEGA-3 XMU operating at $30 \mathrm{kV}, 1 \mathrm{nA}$ ) was used for characterisation of the detrital grain surface. The samples were fixed on a carbon sticker and analysed at the Institute of Physics-UPJŠ at Košice, Slovak Republic.

Table 1. Geographic coordinates (WGS 84) of the HM samples studied.

\begin{tabular}{|c|c|c|c|c|c|c|}
\hline & Sample & Locality & Lithostratigraphy & GPS N & GPS E ${ }^{\circ}$ & Note \\
\hline 1 & BB-8 & Žalobín-nameless stream & Proč Fm. & $48^{\circ} 58^{\prime} 36.7^{\prime \prime}$ & $21^{\circ} 44^{\prime} 39.1^{\prime \prime}$ & Panned concentrate \\
\hline 2 & BB-9 & Žalobín-Žalobínsky potok stream & Proč Fm. & $48^{\circ} 58^{\prime} 35.6^{\prime \prime}$ & $21^{\circ} 45^{\prime} 16.4^{\prime \prime}$ & Panned concentrate \\
\hline 3 & BB-14 & Lieskovec-nameless stream & Proč Fm. & $48^{\circ} 57^{\prime} 55.3^{\prime \prime}$ & $21^{\circ} 49^{\prime} 20.0^{\prime \prime}$ & Panned concentrate \\
\hline 4 & BB-15 & Myslina-Poliaková (stream) & Proč Fm. & $48^{\circ} 57^{\prime} 19.5^{\prime \prime}$ & $21^{\circ} 50^{\prime} 47.6^{\prime \prime}$ & Panned concentrate \\
\hline 5 & BB-19 & Podhorod'-Paprtný vrch hill & Proč Fm. & $48^{\circ} 49^{\prime} 26.0^{\prime \prime}$ & $22^{\circ} 18^{\prime} 37.3^{\prime \prime}$ & HM from compact rock \\
\hline 6 & BB-10 & Giglovce-quarry & Strihovce Fm. & $48^{\circ} 59^{\prime} 54.5^{\prime \prime}$ & $21^{\circ} 44^{\prime} 11.1^{\prime \prime}$ & HM from compact rock \\
\hline 7 & BB-12 & Ohradzany-quarry & Strihovce Fm. & $49^{\circ} 0^{\prime} 2.7^{\prime \prime}$ & $21^{\circ} 50^{\prime} 47.5^{\prime \prime}$ & HM from compact rock \\
\hline 8 & BB-13 & Sopkovce & Strihovce Fm. & $49^{\circ} 0^{\prime} 45.5^{\prime \prime}$ & $21^{\circ} 52^{\prime} 4.2^{\prime \prime}$ & HM from compact rock \\
\hline 9 & BB-16 & Strihovce & Strihovce Fm. & $48^{\circ} 53^{\prime} 49.1^{\prime \prime}$ & $22^{\circ} 16^{\prime} 9.6^{\prime \prime}$ & HM from compact rock \\
\hline 10 & BB-17 & Šmigovec_nameless stream & Strihovce Fm. & $48^{\circ} 53^{\prime} 12.0^{\prime \prime}$ & $22^{\circ} 19^{\prime} 24.2^{\prime \prime}$ & Panned concentrate \\
\hline 11 & BB-18 & Hrabová Roztoka—stream & Strihovce Fm. & $48^{\circ} 52^{\prime} 20.1^{\prime \prime}$ & $22^{\circ} 18^{\prime} 59.5^{\prime \prime}$ & Panned concentrate \\
\hline
\end{tabular}

Table 2. Heavy mineral assemblages of the Proč Ss. (Proč Fm.) and Strihovce Ss. (Strihovce Fm.). The counted grains are assumed to be $100 \%$.

\begin{tabular}{|c|c|c|c|c|c|c|c|c|c|c|c|}
\hline \multirow{2}{*}{$\begin{array}{c}\text { Fm. } \\
\text { Sample }\end{array}$} & \multirow[b]{2}{*}{ BB-8 } & \multirow{2}{*}{\multicolumn{2}{|c|}{$\begin{array}{c}\text { Proč Fm. } \\
\text { BB-14 }\end{array}$}} & \multirow[b]{2}{*}{ BB-15 } & \multicolumn{7}{|c|}{ Strihovce Fm. } \\
\hline & & & & & BB-19 & BB-10 & BB-12 & BB-13 & BB-16 & BB-17 & BB-18 \\
\hline $\mathbf{R t}$ & 12.8 & 8.5 & 9.4 & 11.7 & 8.8 & 15.4 & 10.5 & 10.6 & 9.7 & 4.3 & 11.0 \\
\hline Zrn & 47.1 & 44.7 & 38.8 & 42.9 & 40.9 & 34.6 & 18.5 & 25.7 & 59.1 & 33.5 & 30.7 \\
\hline Tur & 4.5 & 1.4 & 1.1 & 0.4 & 1.4 & 2.1 & 2.6 & 1.3 & 1.9 & 1.4 & 0.9 \\
\hline Ap & 6.4 & 9.6 & 15.3 & 7.4 & 20.7 & 3.5 & 3.0 & 2.2 & 1.6 & 3.2 & 4.5 \\
\hline Grt & 26.0 & 31.6 & 30.7 & 35.8 & 22.1 & 39.9 & 60.5 & 58.4 & 24.1 & 53.8 & 51.0 \\
\hline Ep & 0.3 & tr. & 1.5 & & 1.7 & 0.3 & 1.0 & 0.4 & 0.8 & 0.6 & \\
\hline Sta & 0.3 & & 1.1 & 1.1 & 2.2 & 1.4 & 2.3 & 0.2 & 0.8 & 1.2 & 0.3 \\
\hline Mnz & & & tr. & & tr. & tr. & & & tr. & 0.6 & \\
\hline Spl & 2.6 & 2.8 & 1.5 & 0.7 & 1.9 & 2.1 & 1.6 & 1.1 & 1.9 & 1.4 & 1.5 \\
\hline Brt & & 1.4 & 0.7 & & 0.3 & 0.7 & & & & & \\
\hline Amp & & tr. & & tr. & & & & & & tr. & \\
\hline $\mathrm{Au}$ & & & & & & & & & & tr. & tr. \\
\hline
\end{tabular}

Note: Symbols for minerals are used according to Kretz [72]; tr.- traces. 
Table 3. Representative EMP analyses of detrital Cr-spinels (in wt.\%).

\begin{tabular}{|c|c|c|c|c|c|c|c|c|c|c|c|c|}
\hline \multicolumn{13}{|c|}{ Chromian Spinel } \\
\hline \multirow{2}{*}{$\begin{array}{c}\text { Fm. } \\
\text { Sample }\end{array}$} & \multicolumn{6}{|c|}{ Proč Fm. } & \multicolumn{6}{|c|}{ Strihovce Fm. } \\
\hline & $2 \mathrm{c}$ & $2 r$ & $4 \mathrm{c}$ & $4 r$ & $4 \mathrm{c}$ & $4 r$ & $9 \mathrm{c}$ & $9 r$ & $7 \mathrm{c}$ & $7 \mathrm{o}$ & $6 \mathrm{c}$ & $6 \mathrm{c} 2$ \\
\hline $\mathrm{SiO}_{2}$ & 0.00 & 0.00 & 0.00 & 0.02 & 0.00 & 0.00 & 0.00 & 0.00 & 0.00 & 0.01 & 0.00 & 0.00 \\
\hline $\mathrm{TiO}_{2}$ & 0.12 & 0.21 & 0.00 & 0.08 & 0.63 & 0.91 & 0.16 & 0.09 & 0.95 & 0.84 & 0.09 & 0.01 \\
\hline $\mathrm{Al}_{2} \mathrm{O}_{3}$ & 20.94 & 20.93 & 16.52 & 16.46 & 15.36 & 15.85 & 19.62 & 20.83 & 33.44 & 33.15 & 6.69 & 26.47 \\
\hline $\mathrm{Fe}_{2} \mathrm{O}_{3}$ & 1.50 & 0.94 & 1.38 & 0.88 & 7.85 & 9.19 & 1.16 & 1.77 & 7.11 & 7.36 & 1.31 & 3.90 \\
\hline $\mathrm{FeO}$ & 16.68 & 16.85 & 14.39 & 14.61 & 18.90 & 20.19 & 18.23 & 18.42 & 13.06 & 13.22 & 22.42 & 16.79 \\
\hline $\mathrm{MnO}$ & 0.26 & 0.27 & 0.24 & 0.26 & 0.34 & 0.36 & 0.35 & 0.31 & 0.19 & 0.23 & 0.46 & 0.27 \\
\hline $\mathrm{MgO}$ & 11.72 & 11.45 & 13.01 & 12.75 & 9.55 & 8.75 & 10.41 & 10.45 & 15.19 & 15.06 & 6.44 & 11.99 \\
\hline $\mathrm{Cr}_{2} \mathrm{O}_{3}$ & 48.24 & 48.02 & 54.84 & 54.85 & 46.82 & 44.44 & 48.99 & 47.30 & 28.54 & 28.75 & 62.04 & 39.20 \\
\hline $\mathrm{NiO}$ & 0.08 & 0.06 & 0.08 & 0.12 & 0.14 & 0.17 & 0.01 & 0.06 & 0.16 & 0.15 & 0.00 & 0.14 \\
\hline $\mathrm{ZnO}$ & 0.25 & 0.25 & 0.12 & 0.06 & 0.14 & 0.16 & 0.20 & 0.25 & 0.05 & 0.03 & 0.18 & 0.19 \\
\hline $\mathrm{V}_{2} \mathrm{O}_{5}$ & 0.19 & 0.18 & 0.23 & 0.23 & 0.30 & 0.34 & 0.32 & 0.30 & 0.18 & 0.20 & 0.19 & 0.25 \\
\hline total & 99.98 & 99.15 & 100.81 & 100.32 & 100.03 & 100.35 & 99.44 & 99.78 & 98.87 & 99.00 & 99.82 & 99.21 \\
\hline \multicolumn{13}{|c|}{ Formulae calculated on 3 cations } \\
\hline Si & 0.000 & 0.000 & 0.000 & 0.001 & 0.000 & 0.000 & 0.000 & 0.000 & 0.000 & 0.000 & 0.000 & 0.000 \\
\hline $\mathrm{Ti}$ & 0.003 & 0.005 & 0.000 & 0.002 & 0.016 & 0.022 & 0.004 & 0.002 & 0.021 & 0.018 & 0.002 & 0.000 \\
\hline Al & 0.771 & 0.777 & 0.610 & 0.611 & 0.588 & 0.608 & 0.736 & 0.775 & 1.158 & 1.150 & 0.272 & 0.958 \\
\hline $\mathrm{Fe}^{3+}$ & 0.035 & 0.022 & 0.032 & 0.021 & 0.192 & 0.225 & 0.028 & 0.042 & 0.157 & 0.163 & 0.034 & 0.090 \\
\hline $\mathrm{Fe}^{2+}$ & 0.436 & 0.444 & 0.377 & 0.385 & 0.514 & 0.550 & 0.485 & 0.486 & 0.321 & 0.325 & 0.647 & 0.431 \\
\hline Mn & 0.007 & 0.007 & 0.006 & 0.007 & 0.009 & 0.010 & 0.009 & 0.008 & 0.005 & 0.006 & 0.014 & 0.007 \\
\hline $\mathrm{Mg}$ & 0.546 & 0.538 & 0.607 & 0.599 & 0.463 & 0.42 & 0.494 & 0.492 & 0.666 & 0.661 & 0.331 & 0.549 \\
\hline $\mathrm{Ca}$ & 0.000 & 0.000 & 0.000 & 0.000 & 0.000 & 0.0 & 0.000 & 0.000 & 0.000 & 0.000 & 0.000 & 0.000 \\
\hline $\mathbf{K}$ & 0.000 & 0.000 & 0.000 & 0.000 & 0.000 & 0.000 & 0.000 & 0.000 & 0.000 & 0.000 & 0.000 & 0.000 \\
\hline $\mathbf{N a}$ & 0.000 & 0.000 & 0.000 & 0.000 & 0.000 & 0.000 & 0.000 & 0.000 & 0.000 & 0.000 & 0.000 & 0.000 \\
\hline $\mathrm{Cr}$ & 1.191 & 1.196 & 1.358 & 1.366 & 1.204 & 1.144 & 1.233 & 1.181 & 0.663 & 0.669 & 1.692 & 0.952 \\
\hline $\mathrm{Ni}$ & 0.002 & 0.002 & 0.002 & 0.003 & 0.004 & 0.004 & 0.000 & 0.001 & 0.004 & 0.004 & 0.000 & 0.003 \\
\hline Zn & 0.006 & 0.006 & 0.003 & 0.001 & 0.003 & 0.004 & 0.005 & 0.006 & 0.001 & 0.001 & 0.005 & 0.004 \\
\hline V & 0.004 & 0.004 & 0.005 & 0.005 & 0.006 & 0.007 & 0.007 & 0.006 & 0.003 & 0.004 & 0.004 & 0.005 \\
\hline total & 3.000 & 3.000 & 3.000 & 3.000 & 3.000 & 3.000 & 3.000 & 3.000 & 3.000 & 3.000 & 3.000 & 3.000 \\
\hline Mg\# & & 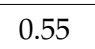 & 0.62 & 0.61 & 0. & 0.44 & 0 & 0.5 & 0.67 & 0.67 & 0.34 & 0.56 \\
\hline Cr\# & 0.61 & 0.61 & 0.69 & 0.69 & 0.67 & 0.65 & 0.63 & 0.60 & 0.36 & 0.37 & 0.86 & 0.50 \\
\hline
\end{tabular}

Note: c: core, $\mathrm{r}$ : $\mathrm{rim} ; \mathrm{Mg} \#=\mathrm{Mg} /\left(\mathrm{Mg}+\mathrm{Fe}^{2+}\right) ; \mathrm{Cr} \#=\mathrm{Cr} /(\mathrm{Cr}+\mathrm{Al})$. The numbers of samples correspond to the numbers in the structure scheme depicted in Figure $1 \mathrm{~b}$ and Table 1.

Table 4. Representative EMP analyses of detrital garnets (in wt.\%).

\begin{tabular}{|c|c|c|c|c|c|c|c|c|c|c|c|c|}
\hline \multicolumn{13}{|c|}{ Garnet } \\
\hline \multirow{2}{*}{$\begin{array}{c}\text { Fm. } \\
\text { Sample }\end{array}$} & \multicolumn{8}{|c|}{ Proč Fm. } & \multicolumn{4}{|c|}{ Strihovce Fm. } \\
\hline & $5 \mathrm{c}$ & $5 \mathrm{r}$ & $4 \mathrm{c}$ & $4 \mathrm{r}$ & $1 \mathrm{c}$ & $1 \mathrm{r}$ & $11 \mathrm{c}$ & $11 r$ & $6 c$ & $6 r$ & $10 \mathrm{c}$ & $10 \mathrm{r}$ \\
\hline $\mathrm{SiO}_{2}$ & 36.94 & 37.71 & 37.35 & 37.64 & 37.00 & 37.39 & 36.76 & 36.81 & 37.72 & 37.95 & 38.46 & 38.29 \\
\hline $\mathrm{TiO}_{2}$ & 0.29 & 0.00 & 0.02 & 0.25 & 0.03 & 0.07 & 0.26 & 0.15 & 0.15 & 0.09 & 0.12 & 0.00 \\
\hline $\mathrm{ZrO}_{2}$ & 0.00 & 0.00 & 0.00 & 0.01 & 0.06 & 0.00 & 0.00 & 0.00 & 0.03 & 0.00 & 0.00 & 0.00 \\
\hline $\mathrm{P}_{2} \mathrm{O}_{5}$ & 0.02 & 0.02 & 0.00 & 0.00 & 0.00 & 0.02 & 0.00 & 0.00 & 0.01 & 0.03 & 0.04 & 0.03 \\
\hline $\mathrm{Y}_{2} \mathrm{O}_{3}$ & 0.03 & 0.00 & 0.02 & 0.02 & 0.00 & 0.04 & 0.03 & 0.00 & 0.01 & 0.04 & 0.04 & 0.03 \\
\hline $\mathrm{Al}_{2} \mathrm{O}_{3}$ & 20.69 & 21.07 & 20.92 & 21.23 & 19.68 & 20.12 & 19.43 & 19.67 & 21.01 & 21.13 & 21.41 & 21.50 \\
\hline $\mathrm{Cr}_{2} \mathrm{O}_{3}$ & 0.05 & 0.06 & 0.00 & 0.01 & 0.01 & 0.01 & 0.01 & 0.05 & 0.03 & 0.06 & 0.01 & 0.01 \\
\hline $\mathrm{V}_{2} \mathrm{O}$ & 0.0 & 0.09 & 0.00 & 0.00 & 0.00 & 0.00 & 0.00 & 0.00 & 0.00 & 0.06 & 0.00 & 0.07 \\
\hline $\mathrm{FeO}$ & 5 & 7.41 & 16.05 & 23.98 & 16.34 & 18 & 10 & 9.87 & 7 & 23 & 28.99 & 28.46 \\
\hline $\mathrm{ZnO}$ & 0.00 & 0.04 & 0.00 & 0.08 & 0.00 & 0.11 & 0.03 & 0.00 & 0. & 0.00 & 0.17 & 0.03 \\
\hline $\mathrm{MnO}$ & 32.03 & 27.82 & 18.51 & 8.86 & 11.63 & 7.00 & 29.56 & 31.51 & 13.82 & 14.56 & 0.54 & 0.65 \\
\hline MgO & 0.12 & 0.44 & 0.22 & 0.35 & 0.70 & 0.71 & 0.09 & 0.11 & 3.63 & 3.22 & 5.70 & 5.76 \\
\hline $\mathrm{CaO}$ & 5.32 & 6.26 & 7.38 & 8.60 & 13.74 & 15.60 & 4.06 & 3.52 & 1.76 & 2.04 & 5.25 & 4.90 \\
\hline $\mathrm{NaO}$ & 0.00 & 0.00 & 0.00 & 0.02 & 0.03 & 0.00 & 0.03 & 0.01 & 0.00 & 0.02 & 0.00 & 0.00 \\
\hline total & 100.81 & 100.93 & 100.48 & 101.03 & 99.19 & 99.68 & 100.94 & 101.68 & 101.37 & 102.49 & 100.71 & 99.73 \\
\hline
\end{tabular}


Table 4. Cont.

\begin{tabular}{|c|c|c|c|c|c|c|c|c|c|c|c|c|}
\hline \multicolumn{13}{|c|}{ Garnet } \\
\hline \multirow{2}{*}{$\begin{array}{c}\text { Fm. } \\
\text { Sample }\end{array}$} & \multicolumn{6}{|c|}{ Proč Fm. } & \multicolumn{6}{|c|}{ Strihovce Fm. } \\
\hline & $5 \mathrm{c}$ & $5 \mathrm{r}$ & $4 \mathrm{c}$ & $4 \mathrm{r}$ & $1 \mathrm{c}$ & $1 \mathrm{r}$ & $11 \mathrm{c}$ & $11 \mathrm{r}$ & $6 \mathrm{c}$ & $6 r$ & $10 \mathrm{c}$ & $10 \mathrm{r}$ \\
\hline \multicolumn{13}{|c|}{ Formulae based on 8 cations, $12 \mathrm{O}$} \\
\hline Si & 2.983 & 3.016 & 3.007 & 2.999 & 2.972 & 2.975 & 2.987 & 2.973 & 2.986 & 2.978 & 2.994 & 3.004 \\
\hline $\mathrm{Ti}$ & 0.017 & 0.000 & 0.001 & 0.015 & 0.002 & 0.004 & 0.016 & 0.009 & 0.009 & 0.005 & 0.007 & 0.000 \\
\hline $\mathrm{Zr}$ & 0.000 & 0.000 & 0.000 & 0.000 & 0.002 & 0.000 & 0.000 & 0.000 & 0.001 & 0.000 & 0.000 & 0.000 \\
\hline $\mathbf{P}$ & 0.002 & 0.002 & 0.000 & 0.000 & 0.000 & 0.001 & 0.000 & 0.000 & 0.001 & 0.002 & 0.003 & 0.002 \\
\hline $\mathbf{Y}$ & 0.001 & 0.000 & 0.001 & 0.001 & 0.000 & 0.002 & 0.001 & 0.000 & 0.001 & 0.002 & 0.001 & 0.001 \\
\hline Al & 1.969 & 1.986 & 1.985 & 1.994 & 1.863 & 1.886 & 1.861 & 1.872 & 1.960 & 1.954 & 1.964 & 1.988 \\
\hline $\mathrm{Cr}$ & 0.003 & 0.004 & 0.000 & 0.000 & 0.000 & 0.000 & 0.000 & 0.003 & 0.002 & 0.004 & 0.000 & 0.000 \\
\hline $\mathbf{V}$ & 0.002 & 0.006 & 0.000 & 0.000 & 0.000 & 0.000 & 0.000 & 0.000 & 0.000 & 0.003 & 0.000 & 0.004 \\
\hline $\mathrm{Fe}^{2+}$ & 0.338 & 0.495 & 1.081 & 1.598 & 0.909 & 1.088 & 0.595 & 0.506 & 1.492 & 1.465 & 1.863 & 1.867 \\
\hline $\mathrm{Fe}^{3+}$ & 0.020 & 0.000 & 0.000 & 0.000 & 0.188 & 0.150 & 0.133 & 0.161 & 0.042 & 0.067 & 0.025 & 0.000 \\
\hline $\mathrm{Zn}$ & 0.000 & 0.002 & 0.000 & 0.005 & 0.000 & 0.006 & 0.002 & 0.000 & 0.003 & 0.000 & 0.010 & 0.002 \\
\hline Mn & 2.191 & 1.884 & 1.262 & 0.598 & 0.791 & 0.472 & 2.034 & 2.156 & 0.927 & 0.968 & 0.035 & 0.043 \\
\hline Mg & 0.014 & 0.053 & 0.026 & 0.042 & 0.084 & 0.084 & 0.011 & 0.013 & 0.428 & 0.376 & 0.661 & 0.674 \\
\hline $\mathrm{Ca}$ & 0.460 & 0.536 & 0.637 & 0.735 & 1.183 & 1.330 & 0.353 & 0.304 & 0.149 & 0.171 & 0.438 & 0.412 \\
\hline $\mathrm{Na}$ & 0.000 & 0.000 & 0.000 & 0.002 & 0.005 & 0.001 & 0.005 & 0.002 & 0.000 & 0.004 & 0.000 & 0.000 \\
\hline Sps & 73.04 & 62.97 & 42.07 & 19.97 & 26.37 & 15.74 & 67.82 & 71.85 & 30.90 & 32.27 & 1.18 & 1.43 \\
\hline Prp & 0.48 & 1.77 & 0.12 & 1.39 & 2.80 & 2.81 & 0.36 & 0.45 & 14.28 & 12.55 & 22.06 & 22.48 \\
\hline Alm & 11.10 & 16.56 & 36.03 & 53.38 & 30.29 & 36.43 & 19.82 & 16.83 & 49.77 & 48.71 & 62.10 & 62.29 \\
\hline Grs & 12.96 & 17.42 & 21.04 & 24.48 & 32.30 & 38.24 & 4.37 & 3.14 & 2.46 & 3.11 & 12.89 & 13.27 \\
\hline Adr & 1.18 & & & & 6.89 & 5.90 & 6.68 & 6.38 & 1.92 & 1.97 & 1.02 & \\
\hline Other & 0.00 & 0.80 & 0.09 & 0.64 & 1.12 & 0.59 & 0.00 & 0.72 & 0.06 & 0.70 & 0.01 & 0.30 \\
\hline
\end{tabular}

Note: Formulae and end-members of garnets (in mol.\%) are calculated according to Locock [73]. Sps — spessartine, Prp-pyrope, Alm—almandine, Grs-grossular, Adr-andradite. The numbers of samples correspond to the numbers in the structure scheme depicted in Figure $1 \mathrm{~b}$ and Table 1.

\section{Results}

The heavy mineral suites of the Palaeocene-Eocene flysch successions are similar. The predominant translucent heavy minerals are metamorphic grains such as garnet, rutile, zircon, apatite, epidote, tourmaline, staurolite and monazite, indicating varying source rock lithologies of the crustal origin, whereas the Cr-spinels suggest subordinate ophiolite provenance (Table 2). Unaltered detrital $\mathrm{Cr}$-spinels were used as a petrogenetic marker to distinguish the tectonic setting of ultramafic and related source rocks. Chromian spinel compositions were plotted in various discriminatory diagrams and compared with existing geochemical Cr-spinel data from Western Carpathian spinel-bearing rocks.

\subsection{Spinel Morphology}

Many chromian spinels from Proč Fm. show euhedral shapes, usually without traces of abrasion on their surfaces (Figure 2a). Corrosive features, such as small etch pits and elongated grooves [6,74] are developed on some grains (Figure $2 b, c)$. Subhedral grains are also present. Slightly rounded spinels are very scarce in the Proč Fm., whereas these are more common in the Strihovce Fm. deposits. Residual, anhedral grains are rare in the Proč Fm., but these are more typical for the Strihovce Fm. The euhedral Cr-spinels displaying the fewest signs of corrosion (Figure 2d), along with those indicating a certain degree of chemical dissolution on the surface were also found in the Strihovce Fm. (Figure 2e,f). 

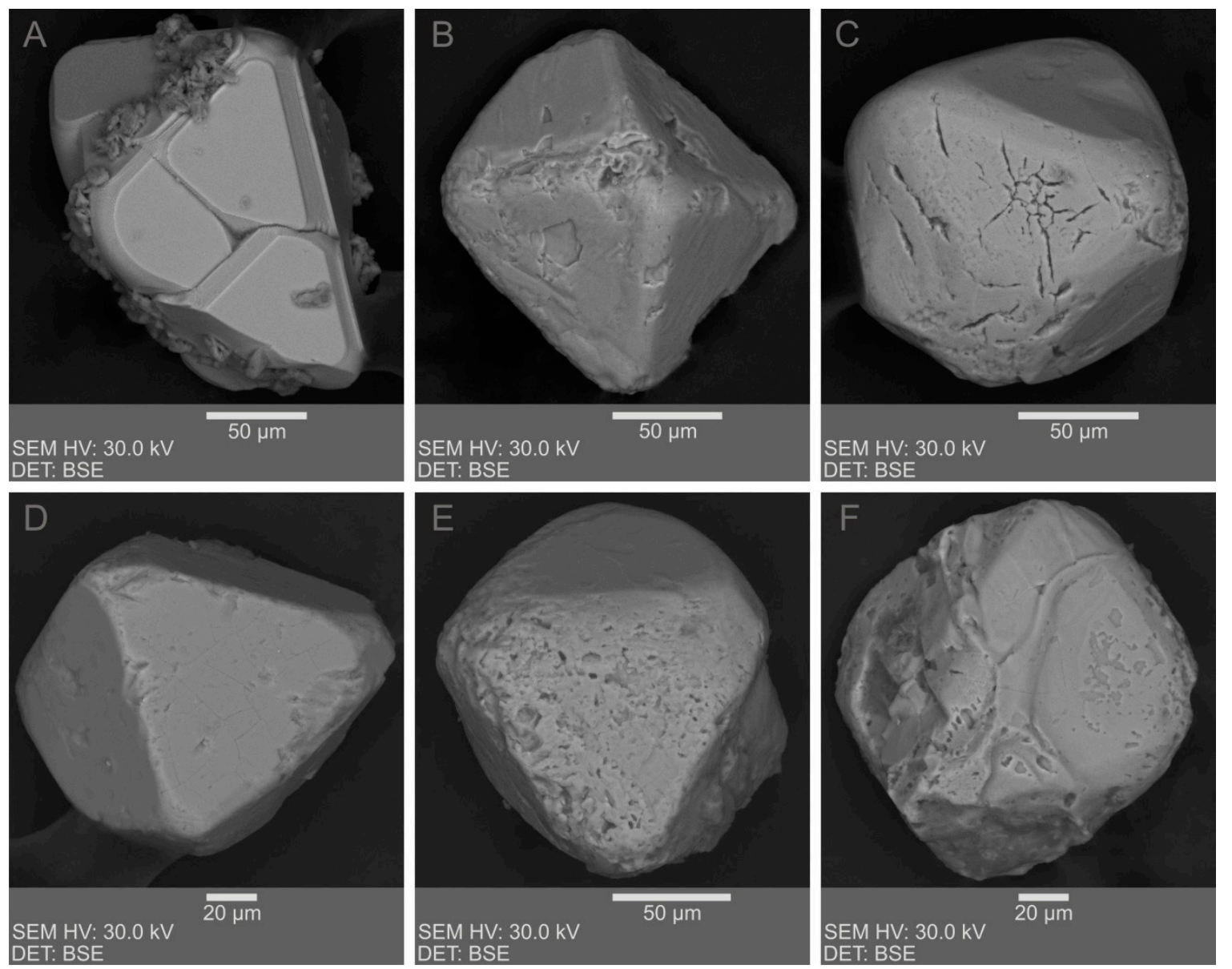

Figure 2. Scanning electron microscope (SEM) images of detrital spinels from the (a-c) Proč Fm. and

(d-f) Strihovce Fm. illustrating their corrosion features. For detailed description, see the text.

\subsection{Internal Texture and Alteration of Spinels}

In this respect, the Proč Fm. spinels are similar to those of the Strihovce Fm. They are usually fresh, unaltered, and not surrounded by magnetite or $\mathrm{Cr}$-chlorite. They have no mineral or melt inclusions (Figure 3a,b). Fine microfractures appear occasionally along the unaltered rims, but grain outlines are not destroyed (Figure 3c). Heavy alteration occurs in individual grain margins or around the fractures which cut the grain (Figure $3 \mathrm{~d}-\mathrm{f}$ ). Another group of $\mathrm{Cr}$-spinels shows decomposition of their internal texture and development of the "myrmekite-like symplectites" [75]. "Myrmekite" appears to have grown inwards from the grain boundaries (Figure 3f). This type of spinel alteration, attended by geochemical changes was also found in the Strihovce grains. A couple of $\mathrm{Cr}$-spinels show concentric compositional zoning indicative of a magmatic crystalline environment. Inclusions of silicate minerals were mainly detected in the detrital $\mathrm{Cr}$-spinels from the Strihovce Fm. Olivine and diopside inclusions are enclosed in the fresh Cr-spinels, according to BSE imaging (Figure 3g,h). Olivine ( $\mathrm{Fo}_{92}$ ) is trapped in peridotitic Cr-spinel, while diopside ( $\mathrm{Wo}_{48.53} \mathrm{En}_{48.55} \mathrm{Fs}_{2.93}$ ) is found in the volcanic grain. At a temperature of $865^{\circ} \mathrm{C}$, measured on the olivine-pyroxene thermometer [76], their re-equilibration in sub-solidus conditions is indicated. There are also chlorite inclusions enclosed in an altered peridotitic Cr-spinel (Figure 3i). 

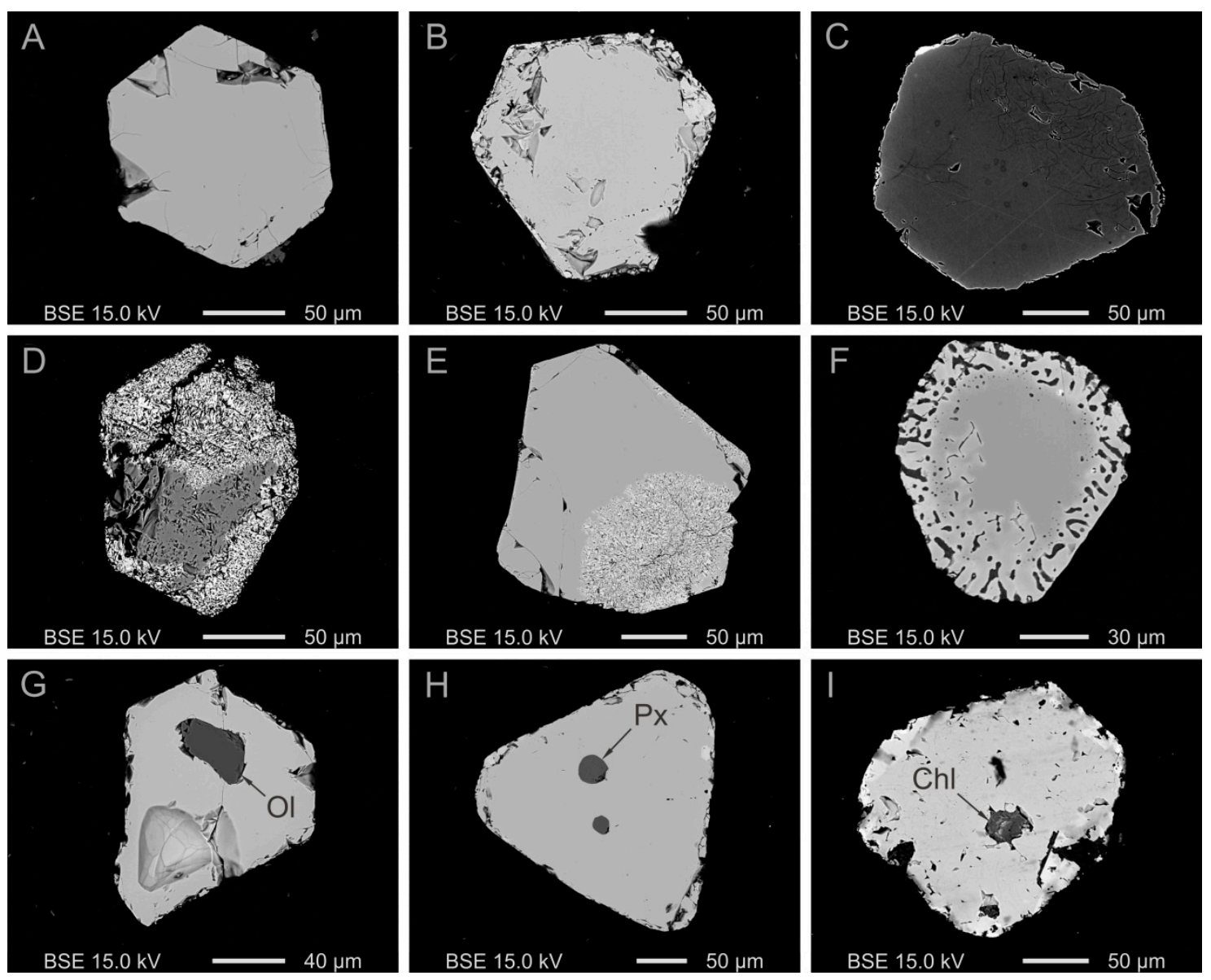

Figure 3. Back-scattered electron images of detrital Cr-spinels: $(\mathbf{a}, \mathbf{b})$ Euhedral spinel shapes (Proč and Strihovce fms, respectively); (c) Fine microfractures along unaltered spinel rim (Strihovce Fm.); $(\mathbf{d}-\mathbf{f})$ alterations of Cr-spinels (Proč Fm.); (g) Olivine (Ol) inclusion trapped in fresh peridotitic spinel (Strihovce Fm.); (h) Diopside (Px) inclusion enclosed in fresh volcanic spinel (Strihovce Fm.); (i) Chlorite (Chl) inclusion enclosed in altered peridotitic spinel (Strihovce Fm.).

\subsection{Spinel Geochemistry}

The contents of $\mathrm{TiO}_{2}, \mathrm{Al}_{2} \mathrm{O}_{3}, \mathrm{Cr}_{2} \mathrm{O}_{3}, \mathrm{FeO}$ and $\mathrm{MgO}$ are crucial for understanding the crystallisation or recrystallisation/alteration history of Cr-spinel [30,77-80]. For the Proč Fm., the $\mathrm{Al}_{2} \mathrm{O}_{3}$ and $\mathrm{TiO}_{2}$ contents of the Cr-spinels vary between 6.27 and $27.83 \mathrm{wt} . \%$ and 0.0 and $3.67 \mathrm{wt} . \%$, respectively (Table 3). The extreme value of $\mathrm{TiO}_{2}=8.08 \mathrm{wt} . \%$ is characteristic for spinel totally transformed to ferritchromite. Alteration indicates a rapid decrease of $\mathrm{Mg}$ and $\mathrm{Al}$, along with an increase in $\mathrm{Fe}$ and, partially, Ti content. $\mathrm{Cr}_{2} \mathrm{O}_{3}$ is usually changeless from the core to the grain periphery, although it slightly increases in some samples. Higher $\mathrm{ZnO}$ (up to $0.27 \mathrm{wt} . \%$ ), $\mathrm{V}_{2} \mathrm{O}_{5}$ (up to $0.31 \mathrm{wt} . \%$ ) and $\mathrm{MnO}$ (up to $0.79 \mathrm{wt} . \%$ ) content values are recorded at the altered margins in comparison to those of the cores. The analysed spinels are classified mainly as chromites and magnesiochromites (Figure 4); exceptionally, gahnite also occurred in the Proč sandstones. 


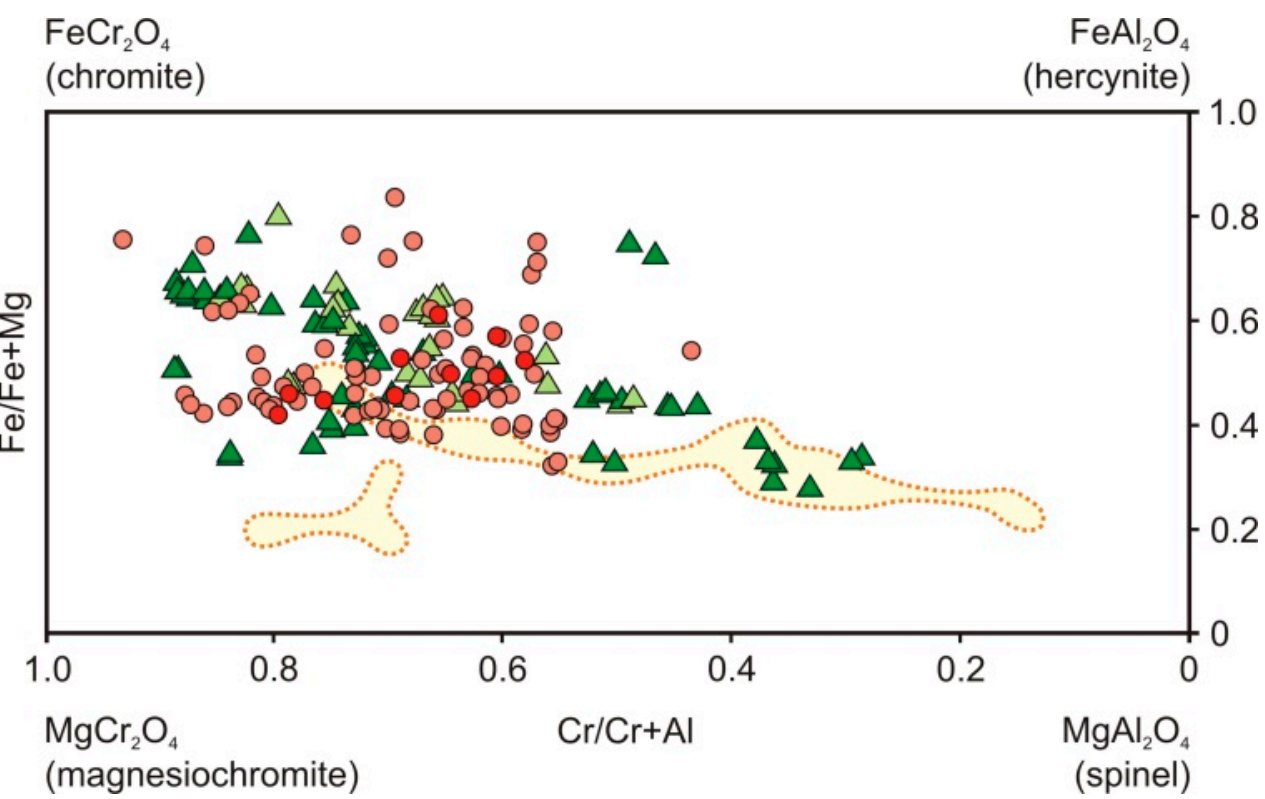

Figure 4. Nomenclature and composition of the studied spinels based on the classification of Deer et al. [16]. The spinels are compared with the compositional (yellow) field of the Poruba Fm. spinels [37]. Explanations: Proč Fm.: red circle-compact rock; pink circle-panned concentrate. Strihovce Fm.: green triangle—compact rock; light green triangle-panned concentrate.

For the Strihovce Fm., new data obtained from the other localities for this study is consistent with previous data [43]. The chemical composition of $\mathrm{Cr}$-spinels reflects very low to high values of $\mathrm{Al}_{2} \mathrm{O}_{3}$ (5.55-39.0 wt.\%). $\mathrm{TiO}_{2}$ content ranges between $0.01 \mathrm{wt} . \%$ and $2.08 \mathrm{wt} . \%$. Cr-spinels define a broad band in $\mathrm{Cr} /(\mathrm{Cr}+\mathrm{Al})$ vs. $\mathrm{Mg} /\left(\mathrm{Mg}+\mathrm{Fe}^{2+}\right)$, as depicted in Figure 5, indicating predominantly harzburgitic affinity. Alteration remarks are similar to those in the Proč chromian spinels. This means a decrease in $\mathrm{Mg}$ and $\mathrm{Al}$, and a considerable increase in $\mathrm{Fe}$, eventually becoming $\mathrm{Fe}^{3+}$.

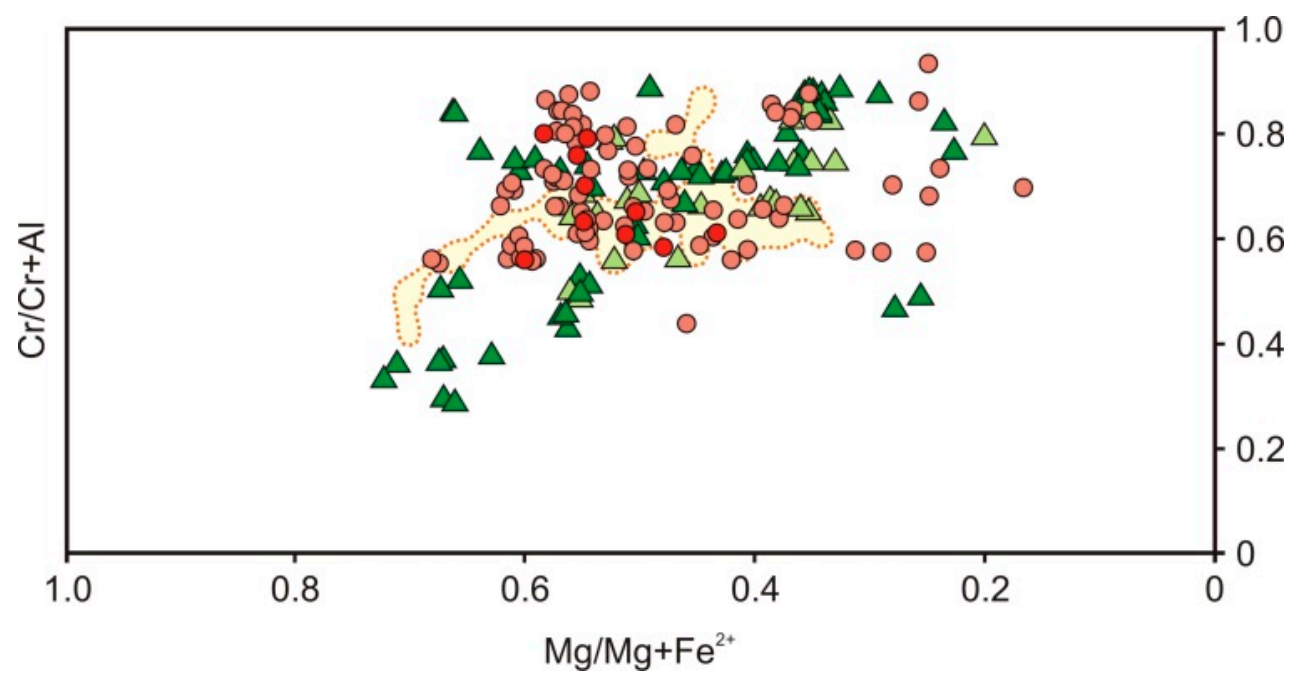

Figure 5. $\mathrm{Mg} /\left(\mathrm{Mg}+\mathrm{Fe}^{2+}\right)$ vs. $\mathrm{Cr} /(\mathrm{Cr}+\mathrm{Al})$ plot of detrital $\mathrm{Cr}$-spinels. Explanations: Proč Fm.: red circle - compact rock; pink circle—-panned concentrate. Strihovce Fm.: green triangle—compact rock; light green triangle-panned concentrate. The spinels are compared with the compositional (yellow) field of the Poruba Fm. spinels [37].

In summary, the analysed chromian spinels show some geochemical variability in the most important elements, such as $\mathrm{Fe}, \mathrm{Mg}, \mathrm{Cr}, \mathrm{Al}$ and Ti. For the Proč Fm., $\mathrm{Cr}_{2} \mathrm{O}_{3}$ - and $\mathrm{TiO}_{2}$-enriched spinels are typical, and $\mathrm{Al}_{2} \mathrm{O}_{3}$ concentration is lower than in the Strihovce Fm. Interestingly, this is true mainly 
for volcanic spinels. The spinel compositions from the Strihovce Fm. show more remarkable variation, mainly in Fe content (Figure 4).

In accordance with Lenaz et al. [14], we discriminate between peridotitic and volcanic spinels on the basis of their $\mathrm{TiO}_{2}$ content and $\mathrm{FeO} / \mathrm{Fe}_{2} \mathrm{O}_{3}$ ratio. Lenaz et al. [14] pointed out that peridotitic spinels show $\mathrm{TiO}_{2}$ content $<0.2 \mathrm{wt} . \%$ and $\mathrm{FeO} / \mathrm{Fe}_{2} \mathrm{O}_{3}>3$, while chromian spinels crystallised from basaltic magmas show $\mathrm{TiO}_{2}$ content $>0.2 \mathrm{wt}$. $\%$ and $\mathrm{FeO} / \mathrm{Fe}_{2} \mathrm{O}_{3}<4$. Mantle spinels of different tectonic settings have distinctive compositions based on the $\mathrm{Al}_{2} \mathrm{O}_{3}$ vs. $\mathrm{TiO}_{2}$ (in wt.\%) discrimination diagram [15]. Detrital peridotitic spinels of both studied formations mostly occupy the field of the supra-subduction zone (Figure 6a); they are strictly harzburgites (Figure 7a). While volcanic spinels from the Proč Fm. were formed chiefly under the OIB and BABB setting, those of the Strihovce Fm. suggest a predominantly MORB origin (Figure 6b). Some detrital volcanic Cr-spinels from the Strihovce Fm. exhibit a lherzolite character (Figure 7b).
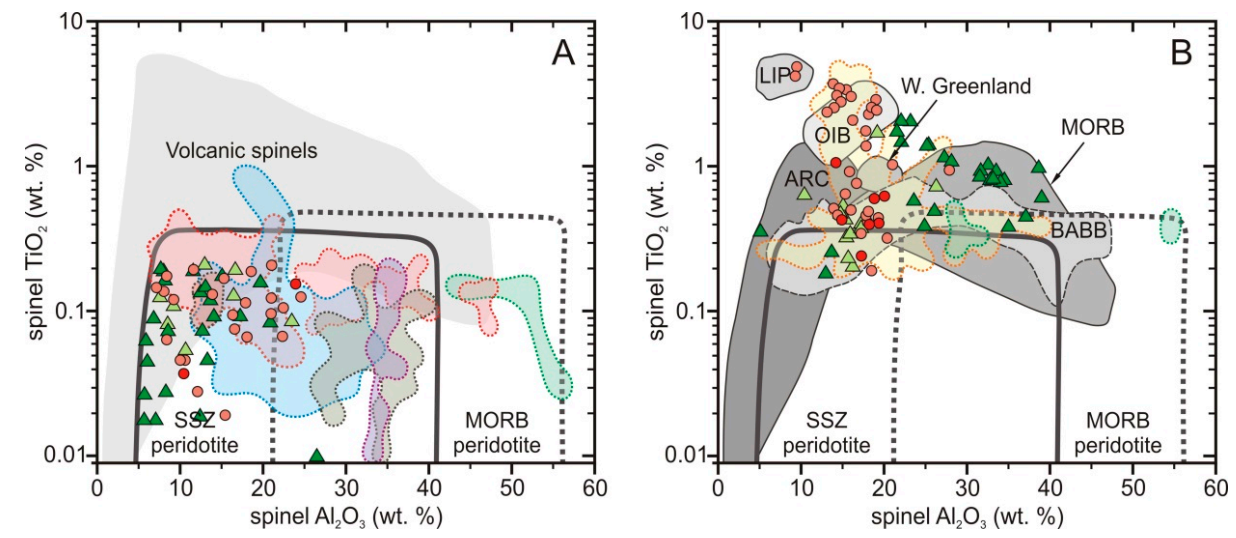

Figure 6. Tectonic discriminating diagram from Kamenetsky et al. [15]: SSZ (supra-subduction zone) peridotite; MORB peridotite; LIP-large igneous provinces; OIB-ocean-island basalt; MORB — mid-ocean ridge basalt; ARC —island-arc basalt; BABB — back-arc basin basalt; (a) for studied peridotitic Cr-spinels; (b) for studied volcanic Cr-spinels. Cr-spinels from the Jarmuta Fm. (PKB; red field) [42], from the Šambron-Kamenica Zone (CCPB; grey field) [39], from the Iňačovce-Krichevo Unit (purple field) [81,82], from the Cretaceous flysch deposits of the Inner Western Carpathians (blue field) [38], from the Marmarosh Klippen Zone (green field) [83], and from the Poruba Fm. (yellow field) [37] are plotted for comparison. Explanations: Proč Fm.: red circle-compact rock; pink circle-panned concentrate. Strihovce Fm.: green triangle-compact rock; light green triangle-panned concentrate.

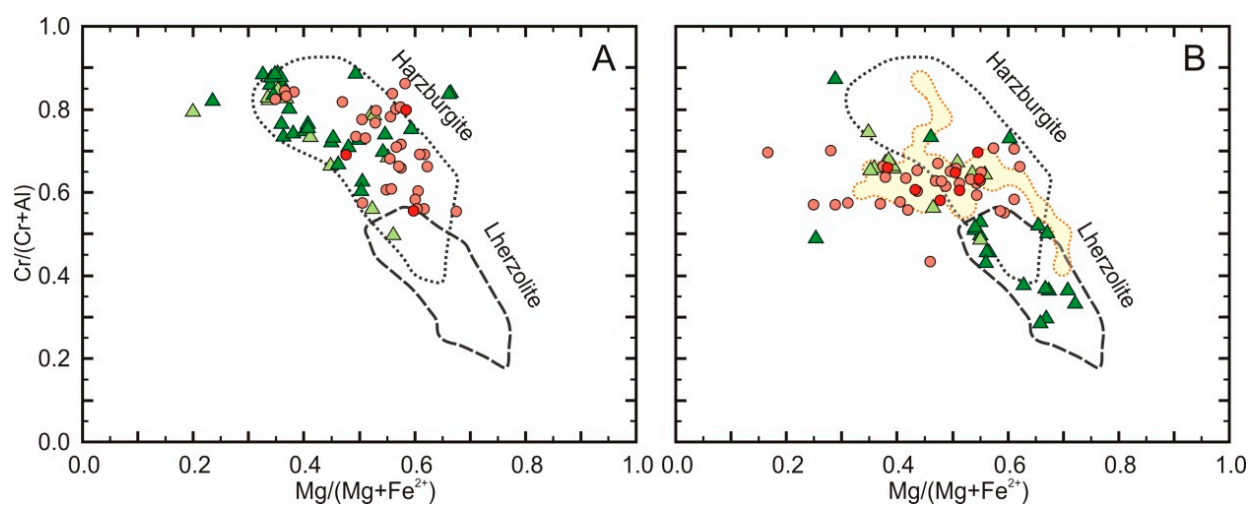

Figure 7. $\mathrm{Mg} /\left(\mathrm{Mg}+\mathrm{Fe}^{2+}\right)$ vs. $\mathrm{Cr} /(\mathrm{Cr}+\mathrm{Al})$ plot for (a) peridotitic and (b) volcanic detrital Cr-spinels. Harzburgite and lherzolite fields are depicted according to Pober and Faupl [19]. Explanations: Proč Fm.: red circle—compact rock; pink circle—-panned concentrate. Strihovce Fm.: green triangle—compact rock; light green triangle-panned concentrate. 


\subsection{Garnet Morphology and Geochemistry}

The surface textures observed on the detrital garnets are similar in both studied formations (Figure 8a-f). Garnets display different degrees of corrosion-from incipient dissolution revealed by small etch pits to fine faceted surfaces [84] (Figure 8a,b). Chemical etching combined with variable extents of mechanical weathering is observed on the same grains (Figure 8c-e). Grains with a predominance of mechanical attrition represented by conchoidal fractures are also observed (Figure 8f).
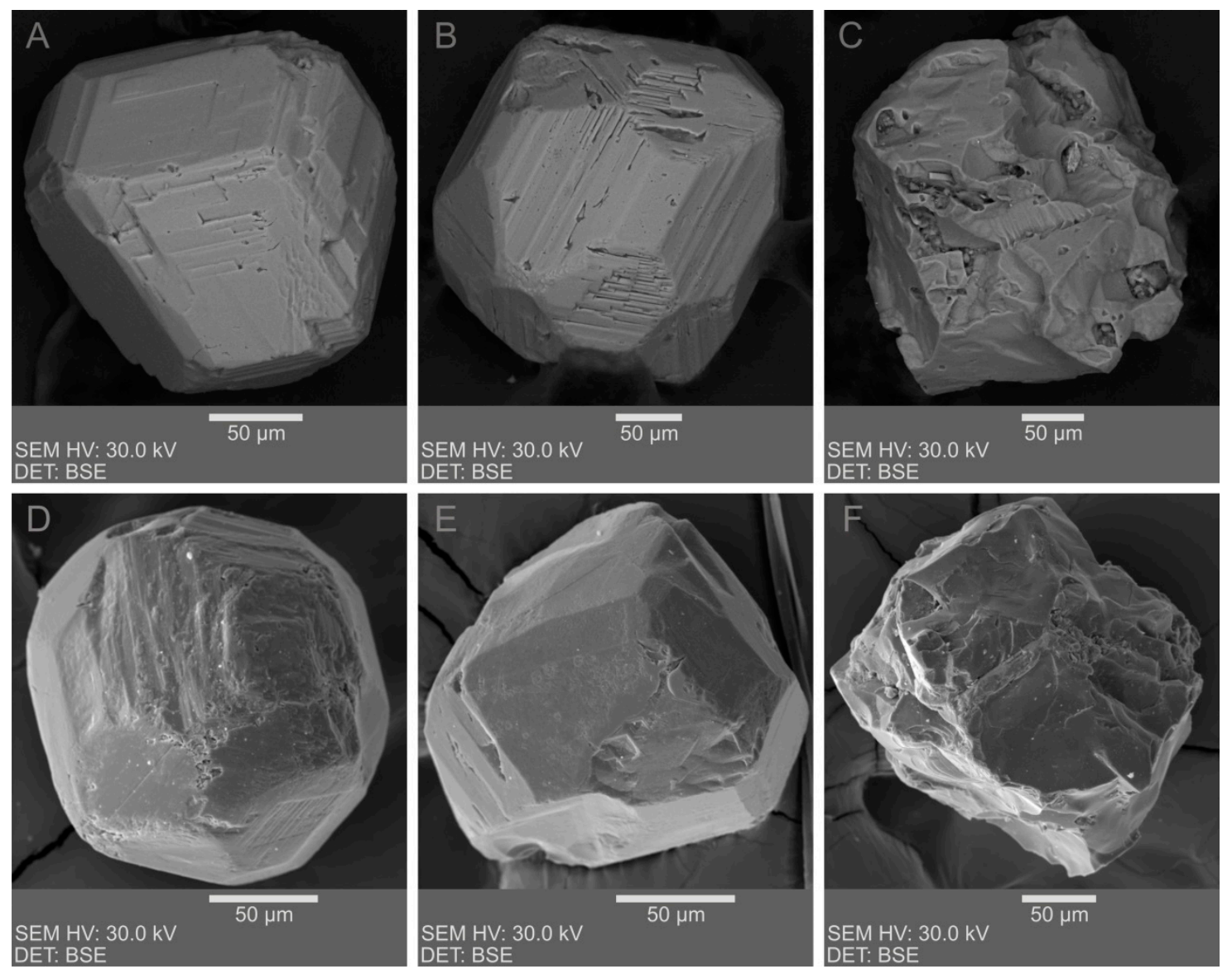

Figure 8. Scanning electron microscope (SEM) images of detrital garnets from the (a-c) Proč Fm. and (d-f) Strihovce Fm., indicating their corrosion features. For detailed description, see the text.

The detrital garnets exhibit analogical composition in both studied formations (Table 4; Figure 9). The analysed garnets are almandine-rich, with various grossular, spessartine and pyrope proportions. The garnets can be subdivided into several groups: almost unzoned pyrope-spessartine-almandine ( $\left.\mathrm{Alm}_{48-65} \mathrm{Sps}_{17-32} \operatorname{Prp}_{10-16} \mathrm{Grs}_{1-3} \mathrm{Adr}_{1-2}\right)$; pyrope-grossular-almandine $\left(\mathrm{Alm}_{50-59} \mathrm{Grs}_{17-34} \operatorname{Prp}_{11-23} \mathrm{Sps}_{0-2} \mathrm{Adr}_{0-3}\right)$; grossular-almandine $\left(\mathrm{Alm}_{62-77} \mathrm{Grs}_{10-30} \mathrm{Sps}_{1-8} \operatorname{Prp}_{4-9} \mathrm{Adr}_{0}\right)$ and zoned almandine-grossular $\left(\mathrm{Grs}_{32-38} \mathrm{Alm}_{30-35} \mathrm{Sps}_{15-26} \operatorname{Prp}_{2} \mathrm{Adr}_{6}\right)$, which was found only in the Proč Fm. deposits; pyrope-almandine $\left(\mathrm{Alm}_{60-79} \operatorname{Prp}_{11-32} \mathrm{Grs}_{2-15} \mathrm{Sps}_{1-7} \mathrm{Adr}_{0-2}\right)$; normal as well as reverse-zoned spessartine-almandines $\left(\mathrm{Alm}_{56-71} \mathrm{Sps}_{18-28} \operatorname{Prp}_{5-10} \mathrm{Grs}_{1-8} \mathrm{Adr}_{0-2}\right)$, which contain inclusions of ilmenite and quartz; spessartine-almandine with grossular ( $\left.\mathrm{Alm}_{40-42} \mathrm{Sps}_{36-38} \mathrm{Grs}_{11} \operatorname{Prp}_{5} \mathrm{Adr}_{2-3}\right)$; almandine-spessartine ( $\left.\mathrm{Sps}_{43-45} \mathrm{Alm}_{41-49} \mathrm{Grs}_{3-6} \mathrm{Adr}_{0-2}\right)$; almandine (up to $89 \mathrm{~mol} \%$ ); spessartine $\left(\mathrm{Sps}_{63-73} \mathrm{Alm}_{11-19} \mathrm{Grs}_{3-17} \operatorname{Prp}_{0-2} \mathrm{Adr}_{1-6}\right)$; and zoned spessartine-almandine with a decrease of $\mathrm{Mn}$ and an increase of Fe and $\mathrm{Ca}$ from the core to the rim $\left(\mathrm{Sps}_{42} \mathrm{Alm}_{36} \mathrm{Grs}_{21} \operatorname{Prp}_{0} \rightarrow \mathrm{Alm}_{53} \mathrm{Sps}_{20} \mathrm{Grs}_{25} \operatorname{Prp}_{1}\right)$ was only found in the Proč sediments. 


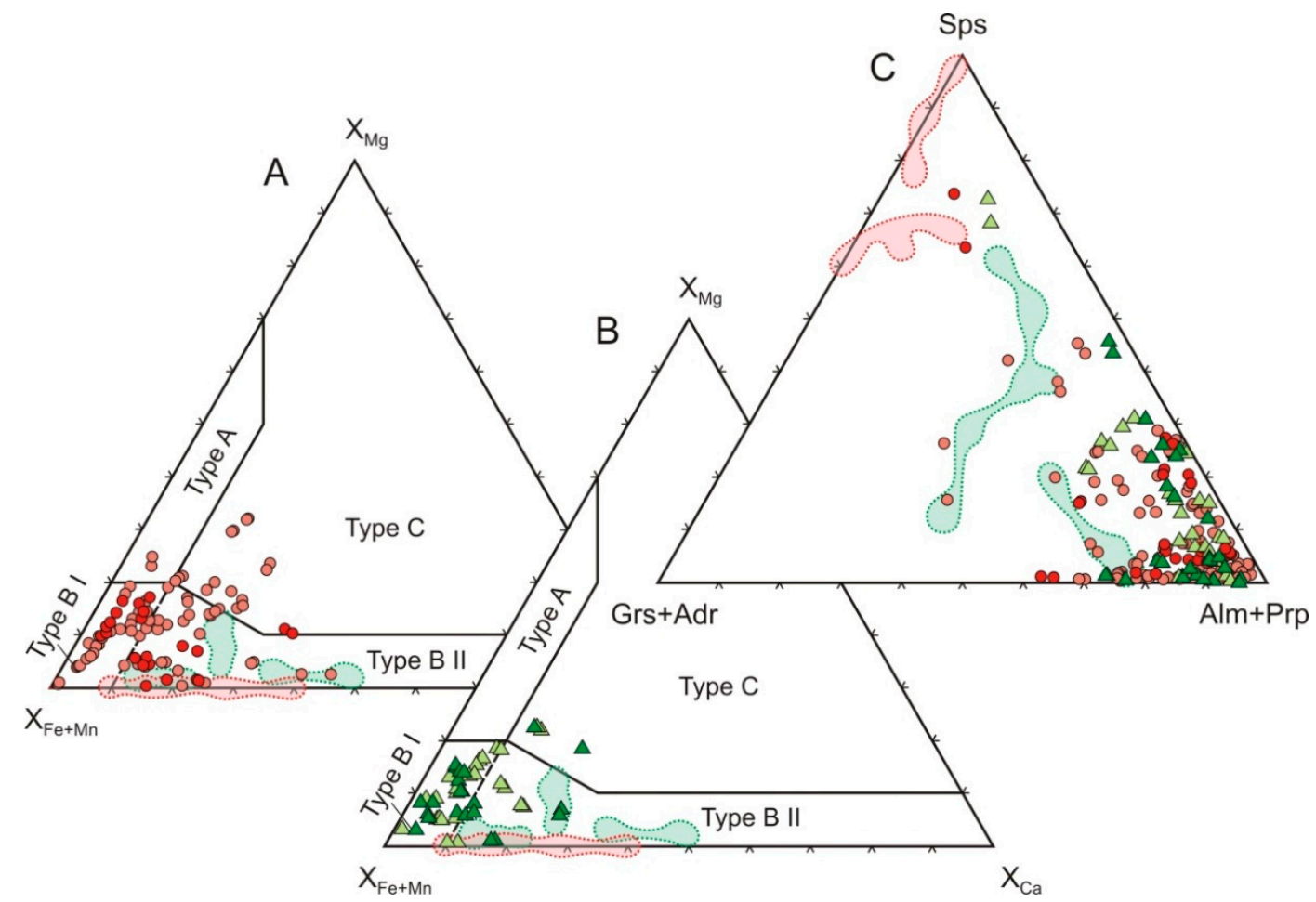

Figure 9. Composition of detrital garnets from the (a) Proč Fm. (red circle-Grt from the compact rock; pink circle-Grt from the panned concentrate) and (b) Strihovce Fm. (green triangle-Grt from the compact rock; light green triangle-Grt from the panned concentrate) in a Fe + Mn-Mg-Ca ternary diagram [9]: type A-Grt from granulites; type B I-Grt from intermediate to acid igneous rocks; type B II-Grt from metasedimentary rocks of amphibolite facies; type C-Grt from metabasic rocks. The garnets are compared with the compositional green field of those from the Meliata $[85,86]$ and Gemer units (pink field) [87]; (c) Garnet ternary diagram expressed in mole fraction of respective cation end-member in garnet for the Proč and Strihovce fms, respectively. Garnet compositions from the Meliata [85,86] and Gemer [87] units are also shown for comparison.

Garnet composition from both studied formations is illustrated in the ternary classification diagram using almandine + spessartine, pyrope and glossular as poles, and discrimination fields $\mathrm{A}$, B I, B II and C (Figure 9a,b) [9]. The garnets of the Proč and Strihovce samples are predominantly plotted in fields B I and B II, for the fields for garnets derived from intermediate to acid igneous and metasedimentary rocks of amphibolite facies, respectively; fewer samples are depicted in the field C, which is typical for garnets derived from metabasic rocks (Figure 9a,b). Detrital garnets are compared to those from the metasediments of the Meliata [85,86] and Gemer [87] units with regard to their spessartine component (Figure 9c).

\section{Discussion}

In terms of the alteration processes, slightly Fe-enriched chromite developed around the grain boundaries is a product of low-temperature serpentinisation of its parent rocks (e.g., $[77,79,88,89]$ ). Sub-greenschist to greenschist facies metamorphism is also documented by the slight increase in $\mathrm{Zn}$ and $\mathrm{Mn}$. Extensive replacement of chromite by ferritchromite with further increase in $\mathrm{Zn}$ and $\mathrm{Mn}$ contents in the spinel rim indicates slightly higher temperature conditions for alteration. Chlorite in spinel is a result of sub-solidus recrystallisation of hosted $\mathrm{Cr}$-spinel during metamorphism or serpentinisation [90]. Bónová et al. [43] described similar alteration/metamorphic phenomena in some detrital chromian spinels from the Eocene Magura turbiditic deposits.

However, the bulk of the analysed spinel grains show zero $\mathrm{SiO}_{2}$ content, indicating no sub-microscopic silicate phases in the place of dissolved elements, which is typical of alteration 
processes $[77,79]$. Depletion in the major element contents $(\mathrm{Mg}, \mathrm{Al})$ in spinels may be a result of component modification and exchange with surrounding silicate minerals, such as olivine and pyroxene [78,91]. In general, based on textural characteristics deducible from the BSE images, the amount of altered spinels is negligible in the investigated dataset. On the other hand, grains reflecting no textural changes but low $\mathrm{Al}_{2} \mathrm{O}_{3}$ could be considered a product of alteration/metamorphism [92]. Nevertheless, they have a relatively high $\mathrm{MgO}$ (10.0-13.33 wt.\%) and low $\mathrm{Fe}_{2} \mathrm{O}_{3}$ (0.14-3.59 wt.\%), and the quantities of these oxides are almost unchanged in the grain centre and on the rim, suggesting original Cr-spinel composition. These Cr-spinels are included in the provenance considerations. Many of the studied spinels are unzoned; this suggests that the parental magma underwent no magma mixing [93], and no notable metamorphic event occurred after the spinel crystallisation [94,95].

The Cr\# value of peridotitic Cr-spinels varies over a wide range, from 0.10 to 0.84 [96,97]. Given that Cr\# values of $0.40-0.60$ are characteristic for both supra-subduction zone (fore-arc) and abyssal peridotites (MORB) [96], values outside this range can be used for diagnostic purposes [98]. As shown in Figure 5, many of the displayed values for Cr\# are more than 0.6 (0.68-0.84). Peridotitic Cr-spinels show identical compositional spectra in both studied formations and unambiguously suggest provenance from a supra-subduction zone [15]. A few grains have a transitional character; these are displayed between SSZ and MORB fields (Figure 6a). This might mean that Cr-spinels originated predominantly from the fore-arc peridotites and were deposited from the same source. There is a noticeable difference between the Proč and Strihovce detrital volcanic spinels. While the Cr-spinels from the Proč Fm. suggest OIB and BABB parental environments, those from the Strihovce Fm. indicate a MORB parentage that could be connected with a nascent spreading centre. Indeed, the volcanic spinels reflect subduction-unrelated varieties.

The detrital Cr-spinels in Mesozoic cover formations from the Western Carpathian units, and especially those from the Poruba Fm., showed affinity to the Meliatic suture zone (Vardar provenance sensu Schmid et al. [57]); these were interpreted to be the Meliata mélange, according to recent investigations [30,31,36,37]. Aubrecht et al. [36] proposed the same conclusion for Cr-spinels from the Aptian/Albian sediments in the Czorsztyn Unit adhered to the PKB. It should be noted that the PKB units indicate a lack of volcanic chromian spinels [30,42], and the Poruba Fm. has up to 37\% of the volcanic spinels in the whole spinel population [37]. Interestingly, the geochemical composition of volcanic Cr-spinels in the Poruba and Proč fms is conspicuously similar (Figure 6b), but not the same (Figure 4). In this case, Plašienka's [99] idea of the progradational trend of the Western Carpathian orogenic wedge development, where the shortening of the Slovakocarpathian continental basement units and subduction of the Penninic oceanic domain indicated gradual outward migration, is thought to be appropriate. This is documented by conglomerates/breccias of various units that are interpreted as vestiges of opening and closure of the Vahic (South Penninic) Ocean. Four principal stages of the recycling process were distinguished with primary erosion and transport of the exotic terigeneous material, generally to the north $[99,100]$. This model could also be used for the transport of the Meliatic detrital material. On the other hand, the Poruba Fm. is similar to the Losenstein Fm. of the Northern Calcareous Alps, providing evidence for a uniform source area to the north with a high Cr-spinel content $[21,101,102]$. Here, the ophiolitic detritus indicates a source area with a South Penninic position [102]. In addition, both formations contain blue sodic amphibole [38,103]. Furthermore, the Poruba Fm. contains pebbles of blueschist facies, which may indicate exhumation of deeper parts of the subduction zone [104]. The same source was considered for the Cretaceous conglomerates occurring in the PKB, which contain blueschist metamorphic rocks [104]. The original idea resulting from the geochemistry of the PKB metabasite pebbles points to their different metamorphic history when compared to the Meliatic blueschists [105-107]. Some investigations suggest a markedly northward extension of the Meliata Ocean [108], and the blueschist-facies pebbles in the Cretaceous flysch formations of the PKB exhibit similar characteristics to the blueschist-facies rocks in the Meliata Unit, so these may be considered to have a Meliatic provenance [109,110]. Besides the 
Meliatic pebbles, the Albian-Cenomanian flysch sediments also contain pebbles from another south source-the Gemer Unit [111,112].

A further fact is that the present-day ophiolites of the Meliata Unit show only lherzolite affinity [30], whereas those from the Palaeocene-Eocene flysch sediments have a predominantly harzburgitic character ([41,43] and this work). Although Ivan [113] presumed variations in basalt composition of the Meliata Ocean from arc-like types through BABBs to types similar to N-MORB, it must be stated that the latter are not preserved in still-extant cover formations. In addition, the chemistry of chromian spinels is hardly distinguishable between the Vardar (Meliata) and Penninic ultramafic rocks [30,40].

It is generally known that spinel is a very resistant mineral; its hardness and lack of cleavage make spinel resistant to mechanical breakdown, so detrital spinel has the potential to survive the weathering and transport process [14,19], and its re-deposition is not surprising. Detrital Cr-spinels found in different Mesozoic sedimentary formations in the Western Carpathian units inherited subhedral to anhedral outlines, or they are the fragments [33,36-38]. The re-deposition would be reflected in the $\mathrm{Cr}$-spinel shapes. The grain shapes of the Proč Cr-spinels suggest a rather short transport of the ophiolitic detrital material and its first-cycle provenance. The proximity of the ultramafic source to the Proč basin might explain the octahedral character of many spinel grains, or the euhedral spinel shape could be related to its mechanical resistance during the transport. The high degrees of roundness of some Cr-spinels from the Strihovce Fm. compared to the Proč Fm. may imply either their re-deposition or the more distal palaeogeografic position of the source area (Figure 2f).

The Rhenodanubian flysch zone, with its continuation into the Magura nappes of the Western Carpathians is considered to be a more southern tectonic element of North Penninic realm [114]. These authors [114] suggested no indications of oceanic basement due to the Rhenodanubian flysch, so these were probably deposited on thinned continental crust. However, Schnabel [115], Plašienka [56] and Schmid et al. $[57,116]$ consider the Rhenodanubian and Magura basins to the Alpine Tethys, so Cr-spinels could theoretically come from ocean floor-related terranes. The ophicalcites found in the western segment of the Magura Unit were inferred to be Alpine-type ophiolites, and may be related to the Magura basement [46].

For comparison, the Eocene-Oligocene samples from the Šambron-Kamenica deposits of the CCPB contain peridotitic spinels, which are plotted in the field overlapping SSZ and MORB peridotite [15], and sporadic volcanic spinels have an OIB character [24]. Palaeotransport directions are variable [21], and Cr-spinel compositions in this zone are heterogeneous. Spišiak et al. [39] considered two different sources for these spinels: the southern Meliata and northern Penninic-Vahic domains, respectively. Of course, the Šambron-Kamenica zone did not supply the Cr-spinels, because of its younger age, but it may be used for comparative purposes.

The currently uncovered part of the Penninicum (Vahicum in Western Carpathian literature) $[117,118]$ occurred in the Transcarpathian Depression basement, known as the Iňačovce-Krichevo Unit [119,120], contains peridotitic $\mathrm{Cr}$-spinels. These spinels, however, have higher $\mathrm{Al}$ (Figure 6a) and lower FeO [82,121] than the spinels studied.

Based on palaeocurrent direction measurements, the detrital material was supplied to the Krynica basin (Strihovce Fm.) generally from the South-East [35,43,48,54,122,123], whereas there are minimal possibilities for sedimentological study in the Proč Fm., and no clear evidence from palaeocurrent data is available. Stráník [124], as well as Leško and Samuel [64], established the palaeotransport of detritus to the Proč basin generally from the South and South-East. Calcareous pattern of the Proč sandstones indicates derivation from the PKB $[64,125]$. In addition, the Proč conglomerates contain a variegated material with prevalence of carbonate rocks; Jurassic facies red limestones were reassembled from the Czorsztyn Unit (PKB), but there are many exotic pebbles derived from the hypothetical, so-called Neopieninic, exotic cordillera of Mišík et al. [44]. This unambiguously establishes the relationship between the PKB and Proč Fm., but it does not solve the volcanic and euhedral peridotitic Cr-spinel origin of the latter. 
As mentioned above, Plašienka [99] supported the idea of multiple recycling of the same exotic material to the still younger conglomerates. The author argued that the still-younger conglomerates (Milpoš Breccia of the Šariš Unit cropping out in the eastern Slovakia) contain both angular carbonate material derived from the PKB successions, and well-rounded siliciclastic exotic material re-deposited from the Sromowce conglomerates of the older Pieniny Unit (for detailed explanation, see $[69,99]$ ). Consequently, Plašienka [99] regarded the Jurassic-Maastrichtian Sub-Pieniny Unit as the source of the Proč-type succession of the Šariš Unit. It should be noted that the Chmielowa Fm. underlying the Jarmuta Fm. of the Sub-Pieniny Unit [69] contains the SSZ peridotitic Cr-spinels and detrital garnets, the geochemistry of which indicates a source from HP/UHP parental rocks [36]. Such high-pyrope garnets are unknown in the Jarmuta [42] and Proč (this work) fms. Although part of the Cr-spinels might have been recycled and derived from this source, the question of the subhedral to euheral peridotitic and volcanic Cr-spinel origin in both studied formations still remains open. Although the detrital Cr-spinels from the Upper Cretaceous-Palaeocene Jarmuta Fm. show wide composition range from the SSZ to MORB (Figure 6a), the certain re-deposition of the ophiolitic detritus, especially of the peridotitic origin can be expected, though the volcanic spinels in this formation are negligible [42]. The palaeocurrent directions from the Jarmuta Fm. sediments indicate material transport predominantly from the south $[42,126]$.

Another possibility is derivation of Cr-spinels from the Marmarosh Klippen Zone [33,44]. However, the peridotitic and volcanic spinels of this zone exhibit diametrically distinct chemical composition [83] to those of the Proč or Strihovce fms (Figure 6a,b).

The heterogeneous geochemical character of the garnets studied indicates their derivation from various types of metamorphic rocks. In addition, garnet is relatively resistant under burial conditions and relatively stable in acidic conditions $[6,74,127]$, but intrastratal solution may cause major variations in the composition of garnet suites. High-Ca garnets are considered less stable than low-Ca garnets $[127,128]$. Corrosive features developed on the garnet surfaces indicate specific weathering and diagenetic dissolution (Figure 8) but the polymict character of the garnets points to a negligible modification of their spectra. Detrital garnets characterised by moderate almandine and grossular molecules may be derived from amphibolites, while garnets derived from gneisses metamorphosed under amphibolite facies conditions show high spessartine content [16,129]. Grossular can occur in the contact metamorphic rocks, such as skarns. The zoned almandine-grossular might be the result of a high-pressure metamorphic event [86]. Grossular-rich garnet is known in blueschist facies metamorphic rocks of the Meliata Unit, but the zoning in this garnet is different-grossular occurred along the cracks and rims of pre-Alpine garnet [86]. Almandine and pyrope-almandine are common in metapelitic rocks, and also in peraluminous granitic rocks with S-type affinity $[129,130]$. High content of the spessartine component in almandine is characteristic of the igneous rocks, such as granites, pegmatites and aplites, or of the metamorphic manganiferous rocks $[16,129,131-133]$. Strongly zoned spessartine garnet is known in the Mn-rich greenschist facies volcano-sedimentary rocks of the Gemer Unit $[87,134]$, and also from the high-pressure rocks of the Meliata Unit $[85,135]$. Regarding the spessartine amount in these parent rocks, its re-deposition to the Proč basin is rather unlikely, but cannot be definitely excluded. Likewise, re-deposition of the detritus from the Proč basin to the Krynica basin can be explained by the presence of the spessartine in the Strihovce Fm. Already Mišík et al. [44] suggested the partial re-deposition of detrital material from the Proč Fm. to the Strihovce Fm. based on the exotic pebble analysis.

Taking into account the palaeogeographic situation during the Palaeocene-Eocene $[42,48,59,136]$, palaeocurrent directions [54,122-124], framework petrography [54,125], Cr-spinel and garnet geochemistry, we assume at least two sources of Cr-spinel supply. The first source might be connected to the partial re-deposition of the detritus from the PKB units, as was suggested in previous studies $[42,49,50]$. This may apply to peridotitic and possibly to BABB volcanic $\mathrm{Cr}$-spinels. The question of the second source remains open and demands further research. This source can be preliminarily inferred to be from the East (outside of the Western Carpathian realm) after application 
of the Western-Carpathian rotation. Assuming a general $50^{\circ}$ counter-clockwise block rotation of the Western Carpathian domains during the late Early Miocene $[137,138]$, the measured palaeocurrent directions for the Palaeogene should be corrected from S to SE (ESE) and from SE-NW to E-W (ENE-WSW).

Despite the partial geochemical similarity between the Proč and Strihovce BABB Cr-spinels, which may be recycled from older sedimentary cycles, there is a group of the Proč OIB-type volcanic spinels characterised by earlier plume activity, followed by the uprising of MORB-type of the Strihovce spinels formed in a rifting setting. The latter type of Cr-spinels is unknown in the exotic flysch units (e.g., Poruba Fm.) from the Western Carpathians. The geochemical differences of two seemingly basaltic series can be related to local variations of the influence of the plume component on the MORB source (e.g., [139]). The volcanic spinels formed in different geodynamic setting, and they could be supplied to the basins from the longitudinal (axial) direction. These spinels are probably not related to Magura oceanic basement subduction [53,70,99], because the trend would rather be inverted. Rare gahnite, which also occurred in the Rača Unit deposits of the Magura Nappe [140], may also point to the axial input of detritus.

\section{Conclusions}

Based on the geochemistry data on the detrital Cr-spinel and garnet in the eastern part of the Western Carpathian Pieniny Klippen and Magura belts, it can be concluded:

1. Detrital spinel chemistry suggests that the sedimentary rocks of both studied formations were partially derived from supra-subduction zone peridotites and also from volcanic rocks; however, the volcanic spinels from the Proč Fm. were formed under an OIB and partially a BABB setting, whereas those from the Strihovce Fm. suggest a predominantly MORB origin.

2. The geochemistry of altered Cr-spinels from the Proč and Strihovce fms deposits points to their parent rocks being subjected to metamorphism of up to the greenschist facies prior to erosion.

3. The similar peridotitic Cr-spinels and garnet geochemistry, and especially the presence of spessartine in both studied formations, may indicate either re-deposition of detrital material from the Upper Palaeocene-Middle? Eocene Proč Fm. to the Middle-Upper Eocene Strihovce Fm., or its supply from the longitudinal (axial) entrance to the basins.

4. In addition to partial recycling of spinel detritus from the Pieniny Klippen Belt units, here it is necessary to consider the further source that has predominantly supplied the volcanic spinels. These spinels evolved during the seafloor spreading, and there is no coincidence with progressive closure the Magura ocean basin. The question of their origin still remains open.

5. Even though Cr-spinels of volcanic origin may indicate different sources for the studied formations, this is not enough to make a clear provenance distinction between them. Similar peridotitic spinel and garnet compositions suggest the relative relationship between the Proč and Strihovce fms, and this preliminarily alludes to the adherence of the Proč Fm. to the Magura Unit in the easternmost part of the Flysch Belt, rather than to the Pieniny Klippen Belt.

Author Contributions: K.B. and J.B. collected the samples; T.M. performed the EMP analyses; K.B., T.M. and J. B. discussed and interpreted the analyses; K.B. and J.B. wrote the paper.

Funding: This work was supported by Grant VEGA 1/0963/17.

Acknowledgments: The authors would like to thank Prof. D. Plašienka and two anonymous reviewers for their prompt reviews of the paper and their useful suggestions, which helped to improve it. Jamson Chen and Jax Jiang are thanked for their careful editorial handling, and guest editor Prof. Davide Lenaz for processing of the paper.

Conflicts of Interest: The authors declare no conflict of interest. 


\section{References}

1. Mange, M.A.; Wright, D.T. Heavy Minerals in Use. Developments in Sedimentology, 1st ed.; Elsevier: Amsterdam, The Netherlands, 2007; Volume 58, pp. 1-1271.

2. von Eynatten, H.; Dunkl, I. Assessing the sediment factory: The role of single grain analysis. Earth Sci. Rev. 2012, 115, 97-120. [CrossRef]

3. Dill, H.G.; Klosa, D. Heavy mineral-based provenance analysis of Mesozoic continental-marine sediments at the western edge of the Bohemian Massif, SE Germany: With special reference to Fe-Ti minerals and the crystal morphology of heavy minerals. Int. J. Earth Sci. 2011, 100, 1497-1513. [CrossRef]

4. Garzanti, E. From static to dynamic provenance analysis-Sedimentary petrology upgraded. Sediment. Geol. 2016, 336, 3-13. [CrossRef]

5. Morton, A.C.; Hallsworth, C.R. Identifying provenance-specific features of detrital heavy mineral assemblages in sandstones. Sediment. Geol. 1994, 90, 241-256. [CrossRef]

6. Morton, A.C.; Hallsworth, C.R. Processes controlling the composition of heavy mineral assemblages in sandstones. Sediment. Geol. 1999, 124, 3-29. [CrossRef]

7. Morton, A.C. A new approach to provenance studies: Electron microprobe analysis of detrital garnets from Middle Jurassic sandstones of the northern North Sea. Sedimentology 1985, 32, 553-566. [CrossRef]

8. Takeuchi, M.; Kawai, M.; Matsuzawa, N. Detrital garnet and chromian spinel chemistry of Permian clastics in the Renge area, central Japan: Implications for the paleogeography of the East Asian continental margin. Sediment. Geol. 2008, 212, 25-39. [CrossRef]

9. Mange, M.A.; Morton, A.C. Geochemistry of heavy minerals. In Heavy Minerals in Use. Developments in Sedimentology, 1st ed.; Mange, M.A., Wright, D.T., Eds.; Elsevier: Amsterdam, The Netherlands, 2007; pp. 345-391.

10. Krippner, A.; Meinhold, G.; Morton, A.C.; von Eynatten, H. Evaluation of garnet discrimination diagrams using geochemical data of garnets derived from various host rocks. Sediment. Geol. 2014, 306, 36-52. [CrossRef]

11. Henry, D.J.; Guidotti, C.V. Tourmaline as a petrogenetic indicator mineral: An example from the staurolite-grade metapelites of NW Maine. Am. Mineral. 1985, 70, 1-15.

12. Zack, T.; von Eynatten, H.; Kronz, A. Rutile geochemistry and its potential use in quantitative provenance studies. Sediment. Geol. 2004, 171, 37-58. [CrossRef]

13. Hiscott, R.N. Ophiolitic source rocks for Taconic-age flysch: Trace-element evidence. J. Geol. Soc. Am. Bull. 1984, 95, 1261-1267. [CrossRef]

14. Lenaz, D.; Kamenetsky, V.S.; Crawford, A.J.; Princivalle, F. Melt inclusion in detrital spinel from the SE Alps (Italy-Slovenia): A new approach to provenance studies of sedimentary basins. Contrib. Mineral. Petrol. 2000, 139, 748-758. [CrossRef]

15. Kamenetsky, V.S.; Crawford, A.J.; Meffre, S. Factors controlling chemistry of magmatic spinel: An empirical study of associated olivine, Cr-spinel and melt inclusion from primitive rocks. J. Petrol. 2001, 42, 655-671. [CrossRef]

16. Deer, W.A.; Howie, R.A.; Zussman, J. An Introduction to the Rock-Forming Minerals, 2nd ed.; Longman: London, UK, 1992; pp. 1-696.

17. Lee, Y.I. Geotectonic significance of detrital chromian spinel: A review. Geosci. J. 1999, 3, 23-29. [CrossRef]

18. Lužar-Oberiter, B.; Mikes, T.; von Eynatten, H.; Babic, L. Ophiolitic detritus in Cretaceous clastic formations of the Dinarides (NW Croatia): Evidence from Cr-spinel chemistry. Int. J. Earth Sci. 2008, 98, 1097-1108. [CrossRef]

19. Pober, E.; Faupl, P. The chemistry of detrital chromian spinels and its implications for the geodynamic evolution of the Eastern Alps. Geol. Rundsch. 1988, 77, 641-670. [CrossRef]

20. Asiedu, D.K.; Suzuki, S.; Shibata, T. Compositions of detrital spinels from Lower Cretaceous Sasayama Group, Hyogo Prefecture, Japan: Constraints on source lithology and tectonic setting. J. Min. Petr. Econ. Geol. 1998, 93, 27-41. [CrossRef]

21. Jablonský, J.; Sýkora, M.; Aubrecht, R. Detritic Cr-spinels in Mesozoic sedimentary rocks of the Western Carpathians (overview of the latest knowledge). Miner. Slovaca 2001, 33, 487-498, (In Slovak with English summary). 
22. Mikes, T.; Christ, D.; Petri, R.; Dunkl, I.; Frei, D.; Báldi-Beke, M.; Reitner, J.; Wemmer, K.; Hrvatović, H.; von Eynatten, H. Provenance of the bosnian Flysch. Swiss J. Geosci. 2008, 101, 31-54. [CrossRef]

23. Abre, P.; Cingolani, C.; Zimmermann, U.; Cairncross, B. Detrital chromian spinels from Upper Ordovician deposits in the Pre-cordillera terrane, Argentina: A mafic crust input. J. S. Am. Earth Sci. 2009, 28, 407-418. [CrossRef]

24. Lenaz, D.; Mazzoli, C.; Spišiak, J.; Princivalle, F.; Maritan, L. Detrital Cr-spinel in the Šambron-Kamenica Zone (Slovakia): Evidence for an ocean-spreading zone in the Northern Vardar suture? Int. J. Earth Sci. 2009, 98, 345-355. [CrossRef]

25. Lužar-Oberiter, B.; Mikes, T.; Dunkl, I.; Babić, L.; von Eynatten, H. Provenance of Cretaceous synorogenic sediments from the NW Dinarides (Croatia). Swiss J. Geosci. 2012, 105, 377-399. [CrossRef]

26. Hu, X.; An, W.; Wang, J.; Garzanti, E.; Guo, R. Himalayan detrital chromian spinels and timing of Indus-Yarlung ophiolite erosion. Tectonophysics 2014, 621, 60-68. [CrossRef]

27. Stankovič, J.; Jančula, D. Preliminary report on the occurence of chromian spinel and Ni minerals on the Jasenie-Kyslá locality, Nízke Tatry Mts. Miner. Slovaca 1982, 14, 131-138, (In Slovak with English abstract).

28. Spišiak, J.; Pitoňák, P.; Petro, M. Metaultramafity z oblasti Jasenie-Kyslá, Nízke Tatry. Miner. Slovaca 1988, 20, 143-148. (In Slovak)

29. Rojkovič, I.; Hovorka, D.; Krištín, J. Spinel group minerals in the West Carpathian ultrabasic rocks. Geol. Zbor. Geol. Carpath 1978, 29, 253-274.

30. Mikuš, T.; Spišiak, J. Chemical composition and alteration of Cr-spinels from Meliata and Penninic serpentinized peridotites (Western Carpathians and Eastern Alps). Geol. Q. 2007, 51, 257-270.

31. Aubrecht, R.; Sýkora, M.; Uher, P.; Li, X.-H.; Yang, Y.-H.; Putiš, M.; Plašienka, D. Provenance of the Lunz Formation (Carnian) in the Western Carpathians, Slovakia: Heavy mineral study and in situ LA-ICP-MS U-Pb detrital zircon dating. Palaeogeogr. Palaeoclimatol. Palaeoecol. 2017, 471, 233-253. [CrossRef]

32. Starobová, M. Těžké minerály východoslovenského magurského flyše a vnitřního bradlového pásma. Geol. Pr. Zoš. 1962, 63, 47-52. (In Czech)

33. Mišík, M.; Jablonský, J.; Fejdi, P.; Sýkora, M. Chromian and ferrian spinels from Cretaceous sediments of the Western Carpathians. Miner. Slovaca 1980, 42, 101-112.

34. Mišík, M.; Jablonský, J.; Fejdi, P.; Sýkora, M. Spinely z kriedových sedimentov Západných Karpát. Folia Fac. Sci. Nat. Univ. Purkynianae Brun. 1981, 22, 95-99. (In Slovak)

35. Mišík, M.; Sýkora, M.; Jablonský, J. Strihovce conglomerates and South-Magura Exotic Ridge (West Carpathians). Západn. Karp. Sér. Geol. 1991, 14, 7-72, (In Slovak with English summary).

36. Aubrecht, R.; Méres, Š.; Sýkora, M.; Mikuš, T. Provenance of the detrital garnets and spinels from the Albian sediments of the Czorstyn Unit (Pieniny Klippen Belt, Western Carpathians, Slovakia). Geol. Carpathica 2009, 60, 463-483. [CrossRef]

37. Mikuš, T.; Spišiak, J.; Sýkora, M.; Demko, R. Chemical composition of spinels from Mesozoic alkali basalts of the Western Carpathians: Implications for sources of detrital spinels in flysch sediments. Geol. Carpathica 2006, 57, 447-460.

38. Bellová, S.; Aubrecht, R.; Mikuš, T. First results of systematic provenance analysis of the heavy mineral assemblages from the Albian to Cenomanian exotic flysch deposits of the Klape Unit, Tatricum, Fatricum and some adjacent units. Acta Geol. Slovaca 2018, 10, 45-64.

39. Spišiak, J.; Soták, J.; Biroň, A.; Mikuš, T. Cr-spinels from serpentinitic sandstone of the Šambron Zone (Eastern Slovakia). Miner. Slovaca 2001, 33, 499-504, (In Slovak with English abstract).

40. Stern, G.; Wagreich, M. Provenance of the Upper Cretaceous to Eocene Gosau Group around and beneath the Vienna Basin (Austria and Slovakia). Swiss J. Geosci. 2013, 106, 505-527. [CrossRef]

41. Lenaz, D.; Winkler, W.; Reusser, E.; Princivalle, F. Preliminary chemical data of detrital Cr spinels from Polish Western Carpathians Flysch. In Proceedings of the 21st Meeting IAS 2001, Davos, Switzerland, 3-5 September 2001; p. 127.

42. Oszczypko, N.; Salata, D. Provenance analyses of the Late Cretaceous-Paleocene deposits of the Magura basin (Polish Western Carpathians)_Evidence from a study of the heavy minerals. Acta Geol. Pol. 2005, 55, 237-267.

43. Bónová, K.; Spišiak, J.; Bóna, J.; Kováčik, M. Chromian spinels from the Magura Unit (Western Carpathians, Eastern Slovakia)—Their petrogenetic and palaeogeographic implications. Geol. Q. 2017, 61, 3-17. [CrossRef] 
44. Mišík, M.; Sýkora, M.; Mock, R.; Jablonský, J. Paleogene Proč Conglomerates of the Klippen Belt in the West Carpathians, material from Neopieninic exotic ridge. Acta Geol. Geogr. Univ. Comen. Geol. 1991, 46, 9-101.

45. Soták, J.; Bebej, J. Serpentinitic sandstone from the Šambron-Kamenica zone in Eastern Slovakia: Evidence of deposition in a Tertiary collisional belt. Geol. Carpathica 1996, 47, 227-238.

46. Soták, J.; Biroň, A.; Spišiak, J. The blocky accumulation of ophicalcites in front of the Magura Unit (Moravia): Their fabrics and possible origin from the sea-floor oceanization. Geol. Carpathica 2002, 53, 48.

47. Marschalko, R.; Mišík, M.; Kamenický, L. Petrographie der Flysch-Konglomerate und Rekonstruktion ihrer Ursprungszonen (Paläogen der Klippenzone und der angrenzenden tektonischen Einkeiten der Ostslowakej). Západn. Karp. Sér. Geol. 1976, 1, 7-124.

48. Bónová, K.; Bóna, J.; Kováčik, M.; Mikuš, T. Heavy minerals and exotic pebbles from the Eocene flysch deposits of the Magura Nappe (Outer Western Carpathians, Eastern Slovakia): Their composition and implications on the provenance. Turk. J. Earth Sci. 2018, 27, 64-88. [CrossRef]

49. Winkler, W.; Ślączka, A. Sediment dispersal and provenance in the Silesian, Dukla and Magura flysch nappes (Outer Carpathians, Poland). Geol. Rundsch. 1992, 81, 371-382. [CrossRef]

50. Winkler, W.; Ślaczka, A. A Late Cretaceous to Paleogene geodynamical model for the Western Carpathians in Poland. Geol. Carpathica 1994, 45, 71-82.

51. Mišík, M.; Reháková, D. Psefitické Horniny (Štrky, Brekcie, Zlepence) Západnúch Karpát, 1st ed.; Veda: Bratislava, Slovakia, 2004; pp. 1-132. (In Slovak)

52. Plašienka, D.; Grecula, P.; Putiš, M.; Hovorka, D.; Kováč, M. Evolution and structure of the Western Carpathians: An overview. In Geological Evolution of the Western Carpathians, 1st ed.; Grecula, P., Hovorka, D., Putiš, M., Eds.; SGIDS: Bratislava, Slovakia, 1997; pp. 1-24.

53. Oszczypko, N. Late Cretaceous through Paleogene evolution of Magura basin. Geol. Carpathica 1992, 43, 333-338.

54. Kováčik, M.; Bóna, J.; Gazdačko, L’.; Kobulský, J.; Maglay, J.; Žecová, K.; Derco, J.; Zlinská, A.; Siráňová, Z.; Boorová, D.; et al. Explanation to the Geological Map of the Nizke Beskydy Mts.—Western Part at Scale 1:50 000, 1st ed.; SGIDS: Bratislava, Slovakia, 2012; pp. 1-180, (In Slovak with English summary).

55. Cieszkowski, M. Marine Miocene deposits near Nowy Targ, Magura Nappe, Flysch Carpathians (South Poland). Geol. Carpathica 1992, 46, 339-346.

56. Plašienka, D. Dynamics of Mesozoic pre-orogenic rifting in the Western Carpathians. Mitt. Österr. Geol. Ges 2003, 94, 79-98.

57. Schmid, S.M.; Bernoulli, D.; Fügenschuh, B.; Matenco, L.; Schefer, S.; Schuster, R.; Tischler, M.; Ustaszewski, K. The Alpine-Carpathian-Dinaridic orogenic system: Correlation and evolution of tectonic units. Swiss J. Geosci. 2008, 101, 139-183. [CrossRef]

58. Plašienka, D. Cretaceous tectonochronology of the Central Western Carpathians (Slovakia). Geol. Carpathica 1997, 48, 99-111.

59. Kováč, M.; Plašienka, D.; Soták, J.; Vojtko, R.; Oszczypko, N.; Less, G.; Ćosović, V.; Fügenschuh, B.; Králiková, S. Paleogene palaeogeography and basin evolution of the Western Carpathians, Northern Pannonian domain and adjoining areas. Glob. Planet. Change 2016, 140, 9-27. [CrossRef]

60. Žec, B.; Gazdačko, L'.; Kováčik, M.; Kobulský, J.; Bóna, J.; Pristaš, J.; Potfaj, M. Geologická Mapa Nízkych Beskýd -Stredná Čast' (1:50 000); MŽP SR, ŠGÚDŠ: Bratislava, Slovakia, 2006. (In Slovak)

61. Žec, B.; Gazdačko, L'; Kováčik, M.; Kobulský, J.; Bóna, J.; Pristaš, J.; Potfaj, M. Vysvetlivky ku Geologickej Mape Nízke Beskydy-Stredná Čast' (1:50 000), 1st ed.; MŽP SR, ŠGÚDŠ: Bratislava, Slovakia, 2011; pp. 1-188, (In Slovak with English summary).

62. Žec, B.; Kaličiak, M.; Konečný, V.; Lexa, J.; Jacko, S.M.; Baňacký, V.; Karoli, S.; Potfaj, M.; Rakús, M.; Petro, L'.; et al. Vysvetlivky ku Geologickej Mape Vihorlatských a Humenských Vrchov M 1:50 000, 1st ed.; GS SR: Bratislava, Slovakia, 1997; pp. 1-254, (In Slovak with English summary).

63. Geological map of Slovakia at scale 1:50,000 [online], 2013. SGIDS: Bratislava, Slovakia. Available online: http:/ / mapserver.geology.sk/gm50js (accessed on 1 April 2008).

64. Leško, B.; Samuel, O. Geológia Východoslovenského Flyšu, 1st ed.; Veda: Bratislava, Slovakia, 1968; pp. 1-245, (In Slovak with English summary).

65. Leško, B. Paleogén bradlového pásma na východnom Slovensku. Geol. Sborník 1960, 11, 95-103, (In Slovak with German summary). 
66. Leško, B.; Began, A.; Franko, O.; Kvitkovič, J.; Kuthan, M.; Seneš, J.; Zorkovský, B. Vysvetlivky k Prehl'adnej Geologickej Mape ČSSR 1:200 000, List M-34-XXIX Snina, 1st ed.; Ústr. Úst. geol.: Bratislava, Czechoslovakia, 1964; pp. 1-132. (In Slovak)

67. Nemčok, J.; Zakovič, M.; Gašparíková, V.; Ďurkovič, T.; Snopková, P.; Vrána, K.; Hanzel, V. Vysvetlivky ku Geologickej Mape Pienin, Čergova, L'ubovnianskej a Ondavskej Vrchoviny v Mierke 1:50 000, 1st ed.; GÚDŠ: Bratislava, Slovakia, 1990; pp. 1-131, (In Slovak with English summary).

68. Potfaj, M.; Tet'ák, F.; Kováčik, M.; Bóna, J. Neoalpínske tektonické jednotky Vonkajších Karpát-Flyšové pásmo. In Vysvetlivky k Prehl'adnej Geologickej Mape Slovenskej Republiky 1:200 000, 1st ed.; Bezák, V., Ed.; ŠGÚDŠ: Bratislava, Slovakia, 2009; pp. 314-333, (In Slovak with English summary).

69. Plašienka, D.; Mikuš, V. Geological setting of the Pieniny and Šariš sectors of the Klippen Belt between Litmanová and Drienica villages in the eastern Slovakia. Miner. Slovaca 2010, 42, 155-178, (In Slovak with English Summary).

70. Plašienka, D.; Soták, J.; Jamrichová, M.; Halászová, E.; Pivko, D.; Józsa, Š.; Madzin, J.; Mikuš, V. Structure and evolution of the Pieniny Klippen Belt demonstrated along a section between Jarabina and Litmanová villages in Eastern Slovakia. Miner. Slovaca 2012, 44, 17-38.

71. Potfaj, M. Skupina bielokarpatských príkrovov. In Vysvetlivky ku Geologickej Mape Stredného Považia M 1:50,000, 1st ed.; Mello, J., Ed.; ŠGÚDŠ: Bratislava, Slovakia, 2011; pp. 139-142, (In Slovak with English summary).

72. Kretz, R. Symbols for rock-forming minerals. Am. Mineral. 1983, 68, 277-279.

73. Locock, A.J. An Excel spreadsheet to recast analyses of garnet into end-member components, and a synopsis of the crystal chemistry of natural silicate garnets. Comput. Geosci. 2008, 34, 1769-1780. [CrossRef]

74. Turner, G.; Morton, A.C. The effects of burial diagenesis on detrital heavy mineral grain surface textures. In Heavy Minerals in Use. Developments in Sedimentology, 1st ed.; Mange, M.A., Wright, D.T., Eds.; Elsevier: Amsterdam, The Netherlands, 2007; pp. 393-412.

75. Kozhoukharova, E. Gr-lherzolites into narrow shear zones of serpentinites from Rhodope Massif, Bulgaria. Ofioliti 1999, 24, 121-122.

76. Roeder, P.L.; Campbell, I.H.; Jameison, H.E. A re-evaluation of the olivine-spinel geothermometer. Contrib. Mineral. Petrol. 1979, 68, 325-334. [CrossRef]

77. Barnes, S.J. Chromite in komatiites, II. Modification during green schist to mid amphibolite facies metamorphism. J. Petrol. 2000, 41, 387-409. [CrossRef]

78. Kimball, K.L. Effects of hydrothermal alteration on the composition of chromian spinels. Contrib. Mineral. Petrol. 1990, 105, 337-346. [CrossRef]

79. Burkhard, D.J.M. Accessory chromium spinels: Their coexistence and alteration in serpentinites. Geochim. Cosmochim. Acta 1993, 57, 1297-1306. [CrossRef]

80. Farahat, E.S. Chrome-spinels in serpentinites and talc carbonates of the El Ideid-El Sodmein District, central Eastern Desert, Egypt: Their metamorphism and petrogenetic implications. Chem. Der Erde-Geochem. 2008, 68, 193-205. [CrossRef]

81. Soták, J.; Križáni, I.; Spišiak, J. On position and material composition of the Merník conglomerates. Acta Geol. Geogr. Univ. Comen. 1990, 45, 55-69.

82. Soták, J.; Biroň, A.; Čverčko, J.; Rudinec, J.; Spišiak, J. Petrology, litostratigraphy and tectonometamorphosis of rock complexes of the Pozdišovce-Iňačovce unit. In III Geologické dni Jána Slávika; Kaličiak, M., Ed.; Geol. Surv. Slovak Rep. Dionýz Štúr Publ.: Bratislava, Slovakia, 1995; pp. 23-31.

83. Bilyk, N.T.; Generalova, L.V.; Yatsenko, I.G.; Stepanov, V.B. Mineralogical and geodynamical conditions of transformation of peridotites from ophiolites in the Marmarosh zone rocks (Ukrainian Carpathians). Geodynamics 2016, 21, 71-83, (In Ukrainian with English summary). [CrossRef]

84. Andò, S.; Garzanti, E.; Padoan, M.; Limonta, M. Corrosion of heavy minerals during weathering and diagenesis: A catalogue for optical analysis. Sediment. Geol. 2012, 280, 165-178. [CrossRef]

85. Faryad, S.W. Petrology and phase relations of low-grade high-pressure metasediments from the Meliata unit, West Carpathians, Slovakia. Eur. J. Miner. 1995, 7, 71-87. [CrossRef]

86. Faryad, S.W.; Frank, W. Textural and age relations of polymetamorphic rocks in the HP Meliata Unit (Western Carpathians). J. Asian Earth Sci. 2011, 42, 111-122. [CrossRef]

87. Faryad, S.W. Mineralogy of Mn-rich rocks from greenschist facies sequences of the Gemericum, West Carpathians, Slovakia. Neues Jahrb. Miner. Monatshefte 1994, 10, 464-480. 
88. Mellini, M.; Rumori, C.; Viti, C. Hydrothermally reset magmatic spinels in retrograde serpentinites: Formation of "ferritchromit" rims and chlorite aureoles. Contrib. Mineral. Petrol. 2005, 149, 266-275. [CrossRef]

89. González-Jiménez, J.M.; Kerestedjian, T.; Profenza, J.A.; Gervilla, F. Metamorphism on chromite ores from the Dobromirtsi Ultramafic Massif, Rhodope Mountains (SE Bulgaria). Geol. Acta 2009, 7, 413-429.

90. Melcher, F.; Grum, W.; Simon, G.; Thalhammer, T.V.; Stumpfl, E.F. Petrogenesis of the ophiolitic giant chromite deposits of Kempirsai, Kazakhstan: A study of solid and fluid inclusions in chromite. J. Petrol. 1997, 38, 1419-1458. [CrossRef]

91. Merlini, A.; Grieco, G.; Diella, V. Ferritchromite and chromian-chlorite formation in mélange hosted Kalkan chromitite (Southern Urals, Russia). Am. Mineral. 2009, 94, 1459-1467. [CrossRef]

92. Power, M.R.; Pirrie, D.; Andersen, J.C.; Wheeler, P.D. Testing the validity of chrome spinel chemistry as a provenance and petrogenetic indicator. Geology 2000, 28, 1027-1030. [CrossRef]

93. Allan, J.F.; Sack, R.O.; Batiza, R. Cr-rich spinels as petrogenetic indicators: MORB-type lavas from the Lamont seamount chain, eastern Pacific. Am. Mineral. 1988, 73, 741-753.

94. Zhu, B.; Kidd, W.S.F.; Rowley, D.B.; Currie, B.S. Chemical compositions and tectonic significance of chrome-rich spinels in the Tianba Flysch, southern Tibet. J. Geol. 2004, 112, 417-434. [CrossRef]

95. Zhu, B.; Delano, J.W.; Kidd, W.S.F. Magmatic compositions and source terranes estimated from melt inclusions in detrital Cr-rich spinels: An example from mid-Cretaceous sandstones in the eastern Tethys Himalaya. Earth Planet. Sci. Lett. 2005, 233, 295-309. [CrossRef]

96. Dick, H.J.B.; Bullen, T. Chromian spinel as a petrogenetic indicator in abyssal and alpine-type peridotites and spatially associated lavas. Contrib. Mineral. Petrol. 1984, 86, 54-76. [CrossRef]

97. Arai, S.; Okamura, H.; Kadoshima, K.; Tanaka, C.; Suzuki, K.; Ishimaru, S. Chemical characteristics of chromian spinel in plutonic rocks: Implications for deep magma processes and discrimination of tectonic setting. Island Arc 2011, 20, 125-137. [CrossRef]

98. Choi, S.H.; Shervais, J.W.; Mukasa, S.B. Supra-subduction and abyssal mantle peridotites of the Coast Range ophiolite, California. Contrib. Mineral. Petrol. 2008, 156, 551-576. [CrossRef]

99. Plašienka, D. Jurassic syn-rift and Cretaceous syn-orogenic, coarse-grained deposits related to opening and closure of the Vahic (South Penninic) Ocean in the Western Carpathians-an overview. Geol. Q. 2012, 56, 601-628. [CrossRef]

100. Plašienka, D.; Soták, J. Evolution of Late Cretaceous-Palaeogene synorogenic basins in the Pieniny Klippen Belt and adjacent zones (Western Carpathians, Slovakia): Tectonic controls over a growing orogenic wedge. Ann. Soc. Geol. Pol. 2015, 43-76. [CrossRef]

101. Wagreich, M. A 400-km-long piggyback basin (Upper Aptian \pm Lower Cenomanian) in the Eastern Alps. Terra Nova 2001, 13, 401-406. [CrossRef]

102. Wagreich, M. A slope-apron succession filling a mid-Cretaceous piggyback basin: The Tannheim and Losenstein Formations of the eastern part of the Northern Calcareous Alps (Austria). Mitt. Österr. Geol. Ges. 2003, 93, 31-54.

103. von Eynatten, H.; Gaupp, R. Provenance of Cretaceous synorogenic sandstones in the Eastern Alps: Constraints from framework petrography, heavy mineral analysis and mineral chemistry. Sediment. Geol. 1999, 124, 81-111. [CrossRef]

104. Ivan, P.; Sýkora, M. Finding of glaucophane-bearing rocks in Cretaceous conglomerates from the Jasenov (Krizna nappe, Eastern Slovakia). Miner. Slovaca 1993, 25, 29-33.

105. Faryad, S.W.; Schreyer, W. Petrology and geological significance of high-pressure metamorphic rocks occurring as pebbles in the Cretaceous conglomerates of the Klippen Belt (Western Carpathians, Slovakia). Eur. J. Miner. 1997, 547-562. [CrossRef]

106. Faryad, S.W. Petrological model for blueschist facies metamorphism in the Pieniny Klippen Belt. In Geological Evolution of the Western Carpathians, 1st ed.; Grecula, P., Hovorka, D., Putiš, M., Eds.; SGIDS: Bratislava, Slovakia, 1997; pp. 155-162.

107. Faryad, S.W.; Henjes-Kunst, F. Petrological and $\mathrm{K}-\mathrm{Ar}$ and ${ }^{40} \mathrm{Ar}-{ }^{39} \mathrm{Ar}$ age constraints for the tectonothermal evolution of the high-pressure Meliata Unit, Western Carpathians (Slovakia). Tectonophysics 1997, 280, 141-156. [CrossRef] 
108. Dal Piaz, G.V.; Martin, S.; Villa, I.M.; Gosso, G.; Marschalko, R. Late Jurassic blueschist facies pebbles from the Western Carpathian orogenic wedge and paleostructural implications for Western Tethys evolution. Tectonics 1995, 14, 874-885. [CrossRef]

109. Ivan, P.; Sýkora, M.; Demko, R. Blueschists in the Cretaceous exotic conglomerates of the Klape unit (Pieniny Klippen Belt, Western Carpathians): Their genetic types and implications for source area. Kwart. AGH Geol. 2006, 32, 47-64.

110. Plašienka, D.; Méres, Š.; Ivan, P.; Sýkora, M.; Soták, J.; Lačný, A.; Aubrecht, R.; Bellová, S.; Potočný, S. Metiatic blueschists and their detritus in Cretaceous sediments: New data constraining tectonic evolution of the Western Carpathians. Swiss J. Geosci. 2018. (submitted).

111. Kissová, D.; Dunkl, I.; Plašienka, D.; Frisch, W.; Marschalko, R. The Pieninic exotic cordillera (Andrusov Ridge) revisited: New zircon FT ages of granite pebbles from Cretaceous flysch conglomerates of the Pieniny Klippen Belt (Western Carpathians, Slovakia). Slovak Geol. Mag. 2005, 11, 17-28.

112. Jeřábek, P.; Lexa, O.; Schulmann, K.; Plašienka, D. Inverse ductile thinning via lower crustal flow and fold-induced doming in the West Carpathian Eo-Alpine collisional wedge. Tectonics 2012, 31, 1-26. [CrossRef]

113. Ivan, P. Relics of the Meliata ocean crust: Geodynamic implications of mineralogical, petrological and geochemical proxies. Geol. Carpathica 2002, 53, 245-256.

114. Faupl, P.; Wagreich, M. Cretaceous flysch and pelagic sequences of the Eastern Alps: Correlations, heavy minerals, and palaeogeographic implications. Cretac. Res. 1992, 13, 387-403. [CrossRef]

115. Schnabel, W. New data on the Flysch zone of the Eastern Alps in the Austrian sector and new aspects concerning the transition to the Flysch Zone of the Carpathians. Cretac. Res. 1992, 13, 405-419. [CrossRef]

116. Schmid, S.M.; Fügenschuh, B.; Kissling, E.; Schuster, R. Tectonic map and overall architecture of the Alpine orogen. Eclogae Geol. Helv. 2004, 97, 93-117. [CrossRef]

117. Mahel', M. Geological structure of the Czechoslovak Carpathians. Paleoalpine Units, 1st ed.; Veda: Bratislava, Czechoslovakia, 1986; pp. 1-496.

118. Plašienka, D. Mid-Cretaceous (120-80 Ma) orogenic processes in the central Western Carpathians: Brief review and interpretation of data. Slovak Geol. Mag. 1996, 3, 319-324.

119. Soták, J.; Rudinec, R.; Spišiak, J. The Penninic "pull-apart" dome in the pre-Neogene basement of the Transcarpathian Depression (Eastern Slovakia). Geol. Carpathica 1993, 44, 11-16.

120. Soták, J.; Spišiak, J.; Biroň, A. Metamorphic sequences with "Bündnerschiefer" lithology in the pre-Neogene basement of the East Slovakian Basin. Mitt. Österr. Geol. Ges. 1994, 86, 111-120.

121. Soták, J.; Križáni, I.; Spišiak, J. Position and sedimentology of Mernik conglomerates. Geol. Pr. Správy. 1991, 92, 53-69. (In Slovak)

122. Koráb, T.; Nemčok, J.; Ďurkovič, T.; Marschalko, R. Prehl'adný výskum orientovaných sedimentárních textúr vo flyši východného Slovenska. Geol. Sb. 1962, 13, 257-274, (In Slovak with English summary).

123. Bóna, J.; Gazdačko, L'.; Kobulský, J.; Maglay, J.; Kučera, M. Geological map of the Nízke Beskydy Mts.-Western Part at Scale 1:50 000; Kováčik, M., Ed.; SGIDS: Bratislava, Slovakia, 2011.

124. Stráník, Z. Geology of the Magura Flysch of the Čergov Mts. and western part of the Ondavská vrchovina hills. Sbor. Geol. Vied Západ. Karp. 1965, 3, 125-173.

125. Ďurkovič, T. Sedimentárno-petrografický výskum pročských vrstiev beňatínskeho flyšu na východnom Slovensku. Geol. Pr. Spráoy 1972, 58, 119-124. (In Slovak)

126. Nemčok, J. Magurský príkrov a bradlové pásmo na východnom Slovensku. Geol. Pr. Správy 1984, 81, 119-129. (In Slovak)

127. Morton, A.C.; Hallsworth, C. Stability of detrital heavy minerals during burial diagenesis. In Heavy Minerals in Use. Developments in Sedimentology, 1st ed.; Mange, M.A., Wright, D.T., Eds.; Elsevier: Amsterdam, The Netherlands, 2007; pp. 215-245.

128. Morton, A.C. Influences of provenance and diagenesis on detrital garnet suites in the Paleocene Forties Sandstone, Central North Sea. J. Sediment. Res. 1987, 57, 1027-1032.

129. Deer, W.A.; Howie, R.A.; Zussman, J. Rock-Forming Minerals, Orthosilicates, 2nd ed.; Geol. Soc.: London, UK, 1997; pp. 1-919.

130. Broska, I.; Petrík, I.; Uher, P. Akcesorické minerály granitoidných hornín Západných Karpát; Veda: Bratislava, Slovakia, 2012; pp. 1-235, (In Slovak with English summary).

131. Faryad, S.W.; Dianiška, I. Garnets from granitoids of the Spišsko-gemerské Rudohorie Mts. Geol. Zb. Geol. Carpathica 1989, 40, 715-734. 
132. Morton, A.C.; Hallsworth, C.R.; Chalton, B. Garnet compositions in Scottish and Norwegian basement terrains: A framework for interpretation of North Sea sandstone provenance. Mar. Petrol. Geol. 2004, 21, 393-410. [CrossRef]

133. Méres, Š. Garnets-important information resource about source area and parental rocks of the siliciclastic sedimentary rocks. In Cambelove Dni; Abstract book; Jurkovič, L'., Ed.; Comenius University: Bratislava, Slovakia, 2008; pp. 37-43, (In Slovak with English abstract).

134. Spišiak, J.; Hovorka, D.; Rybka, R.; Turan, J. Spessartine and piemontite in Lower Palaeozoic metasediments of the Inner West Carpathians. Čas. Miner. Geol. 1989, 34, 17-32, (In Slovak with English summary).

135. Faryad, S.W. Lithology and metamorphism of the Meliata unit high-pressure rocks. In Geological Evolution of the Western Carpathians, 1st ed.; Grecula, P., Hovorka, D., Putiš, M., Eds.; SGIDS: Bratislava, Slovakia, 1997; pp. 131-144.

136. Golonka, J.; Gahagan, L.; Krobicki, M.; Marko, F.; Oszczypko, N.; Ślączka, A. Plate Tectonic Evolution and Paleogeography of the Circum-Carpathian Region. In The Carpathians and Their Foreland: Geology and Hydrocarbon Resources, 1st ed.; Golonka, J., Picha, F., Eds.; American Association of Petroleum Geologists Memoir: Tulsa, OK, USA, 2006; Volume 84, pp. 11-46.

137. Márton, E.; Grabowski, J.; Plašienka, D.; Túnyi, I.; Krobicki, M.; Haas, J.; Pethe, M. New paleomagnetic results from the Upper Cretaceous red marls of the Pieniny Klippen Belt, Western Carpathians: Evidence for general CCW rotation and implications for the origin of the structural arc formation. Tectonophysics 2013, 592, 1-13. [CrossRef]

138. Márton, E.; Grabowski, J.; Tokarski, A.; Túnyi, I. Palaeomagnetic results from the fold and thrust belt of the Western Carpathians: An overview. In Palaeomagnetism in Fold and Thrust Belts: New Perspectives, Spec. Publ., 1st ed.; Pueyo, E.L., Cifelli, F., Sussman, A.J., Oliva-Urcia, B., Eds.; Geological Society: London, UK, 2015; Volume 425, pp. 7-36.

139. Saccani, E.; Seghedi, A.; Nicolae, I. Evidence of rift magmatism from preliminary petrological data on lower Triassic mafic rocks from the North Dobrogea orogeny (Romania). Ofioliti 2004, 29, 231-241.

140. Bónová, K. Ťažké minerály v pieskovcových súvrstviach magurského pásma na východnom Slovensku—Proveniencia a paleogeografické implikácie, 1st ed.; UPJŠ: Košice, Slovakia, 2018; pp. 1-186, (In Slovak with English summary).

(C) 2018 by the authors. Licensee MDPI, Basel, Switzerland. This article is an open access article distributed under the terms and conditions of the Creative Commons Attribution (CC BY) license (http:/ / creativecommons.org/licenses/by/4.0/). 